\title{
La conquista de América en la Ilustración francesa y española: Montesquieu y Cadalso ${ }^{1}$
}

\section{The conquest of America in the French and Spanish Enlightenment: Montesquieu and Cadalso}

\author{
Francisco Castilla Urbano ${ }^{2}$ \\ Universidad de Alcalá (España)
}

Recibido: 03-07-18

Aprobado: 24-07-18

\section{Resumen}

Más allá de las coincidencias formales que puedan establecerse entre las Cartas marruecas y las Lettres persanes, las obras de los ilustrados José Cadalso y Montesquieu están unidas por un debate sobre temas tan diversos como la naturaleza del gobierno, el valor de la virtud política, el sentido de la cultura, el carácter de los pueblos, etc. En este artículo se analizan los contenidos de su polémica sobre la conquista y colonización de América.

Palabras-clave: José Cadalso, Montesquieu, conquista de América, Ilustración.

\footnotetext{
${ }^{1}$ Este artículo se ha realizado en el marco del proyecto de investigación "Discursos legitimadores de la conquista y la colonización de América al norte y al sur del continente" (Instituto FranklinUAH 2011-007). Se ha beneficiado, asimismo, de una estancia en la Université Michel de MontaigneBordeaux3.

2 (francisco.castilla@uah.es) Profesor Titular de Filosofía de la Universidad de Alcalá. Sus investigaciones se centran en la metodología de la historia de las ciencias sociales (El análisis social de Julio Caro Baroja: empirismo y subjetividad, 2002), y en el pensamiento moderno, especialmente en relación con América, donde se sitúan sus libros El pensamiento de Francisco de Vitoria. Filosofía política e indio americano (1992); Juan Ginés de Sepúlveda (1490-1573) (2000), la edición del Diálogo llamado Demócrates (2012), de este último autor, y El pensamiento de Juan Ginés de Sepúlveda: vida activa, humanismo y guerra en el Renacimiento (2013). Es editor de Discursos legitimadores de la conquista y la colonización de América (2014), Visiones de la conquista y la colonización de las Américas (2015) y, en colaboración con $\mathrm{M}^{\mathrm{a}}$. José Villaverde, La sombra de la leyenda negra (2016). https://portal.uah.es/portal/page/portal/epd2_profesores/prof121894
} 


\begin{abstract}
Beyond the formal matches that can be established between the Cartas marruecas and the Lettres persanes, the works of the philosophers José Cadalso and Montesquieu are joined by a discussion on topics as diverse as the nature of government, the value of virtue politics, the meaning of culture, the character of the people, etc. In this paper we analyze the contents of their polemic on the conquest and colonization of America.
\end{abstract}

Key-words: José Cadalso, Montesquieu, conquest of America, Enlightenment.

\title{
1. Introducción
}

El objetivo de este trabajo es analizar la obra de José Cadalso en relación a la de Montesquieu y, en concreto, las manifestaciones de ambos sobre la conquista y colonización de América.

Existe una abundante bibliografía que pone en relación a ambos autores, hasta el punto de obligar a su recopilación hace casi un siglo a quien parece haber sido el primero en pasar de la mera mención al análisis ${ }^{3}$. La opinión de Tamayo, repetida insistentemente en su estudio, es que "la imitación se reduce al artificio de las cartas, al pretexto para presentar al público aquella serie de observaciones de carácter histórico y social, pero no trasciende al contenido en el cual la desemejanza es completa"4. Sin embargo, haciéndose eco de los que ven en las Cartas marruecas una defensa de España frente a las afirmaciones de Montesquieu, no deja de reconocer que

\begin{abstract}
"sólo podría encontrarse algo parecido a intento de oposición doctrinal en los numerosos pasajes de las Cartas Marruecas, que son una exaltación de la aventura de la conquista del continente americano por los españoles. Pero entonces había que decir que Cadalso no se propuso combatir las opiniones expuestas por Montesquieu en las Lettres Persanes porque este escritor es en otra obra, 'De l'esprit des lois', en donde hace una acerba crítica de la dominación española en América"s.
\end{abstract}

Tamayo no desarrolló esta cuestión y hay que esperar otros veinticinco años para que Paul Laborde publique un texto fundamental para la comparación

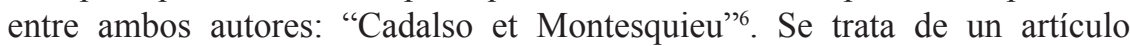

${ }^{3}$ J. Tamayo y Rubio, "Cartas Marruecas del Coronel D. Joseph Cadahalso", Anales de la Facultad de Filosofia y Letras (Universidad de Granada), 2, 1926, pp. 123-36 y 3, 1927, pp. 7-85 (49-52).

4 Ibid., pp. 133-34.

5 Ibid., p. 9.

${ }^{6}$ P. Laborde, “Cadalso et Montesquieu”, Revue des Langues Romanes, LXXI, 1952, pp. 171-80.

Araucaria. Revista Iberoamericana de Filosofia, Política, Humanidades y Relaciones Internacionales, año $20, \mathrm{n}^{\circ} 40$. Segundo semestre de 2018. Pp. 75-107. ISSN 1575-6823 e-ISSN 2340-2199 doi: 10.12795/araucaria.2018.i40.04 
valioso, que se ocupa exclusivamente del vínculo entre las Cartas marruecas y las Cartas persas, para reivindicar que es de esta obra de Montesquieu y no del Ciudadano del mundo de Oliver Goldsmith, como habían empezado a mantener algunos autores británicos y alemanes, de donde surge la inspiración de la obra del español. Dos son los argumentos fundamentales utilizados por Laborde en su artículo: por una parte, cita un importante número de autores que habían defendido esta influencia ${ }^{7}$; por otra parte, lleva a cabo un estudio comparado entre las dos obras para demostrar sus coincidencias textuales. Entre éstas, menciona brevemente la carta IX, "consagrada a un magnífico elogio de Hernán Cortés, respuesta a las críticas de Montesquieu sobre la conquista y la colonización de América"».

Otro texto fundamental es la Defensa de la nación española contra la carta persiana LXXVIII de Montesquieu. Paul Laborde no pudo tenerlo en cuenta porque su descubrimiento y publicación por el profesor Guy Mercadier es casi veinte años posterior a su artículo9. La edición se centra, más que en cuestiones ideológicas, en determinar la autoría de Cadalso, las fuentes de las que se sirvió y las que pudo tener en cuenta en su respuesta. Por eso, Mercadier se limita a recordar en una nota a pie de página que la carta marrueca novena desarrolla el tema de la conquista del Nuevo Mundo ${ }^{10}$.

No hay prácticamente ninguna edición de las obras de Cadalso, especialmente de las Cartas marruecas, que no preste atención a la relación con las Cartas persas. Sin embargo, la propia índole de estos trabajos, que suelen consistir en introducciones generales a la vida y obra de Cadalso o específicas a las Cartas marruecas, hace que sus autores no se ocupen detalladamente de un asunto tan definido como es la conquista de América en Montesquieu y Cadalso. Una excepción que merece la pena recordar, a pesar de su brevedad, es el prólogo a la edición de Lucien Dupuis y Nigel Glendinning, donde proporcionan una relación probable de los autores y libros europeos que pudo tener en cuenta Cadalso en relación a la conquista de América ${ }^{11}$. Aparecen en la misma algunas obras de Montesquieu, Vattel, Voltaire y Raynal, aunque tal vez habría que añadir a Rousseau y, posiblemente, a Hume ${ }^{12}$.

${ }^{7}$ Ibid., pp. 171-72: Menéndez Pelayo, Cejador y Frauca, Cotarelo y Mori, Juan Hurtado y Ángel González Palencia, así como Marcel Duviols; muchos de ellos habían sido citados anteriormente por E. Cotton, "Cadalso and his foreign sources", Bulletin of Spanish Studies, VIII, 29, 1931, pp. 5-18.

${ }^{8}$ Ibid., p. 179.

9 J. de Cadalso, Defensa de la nación española contra la carta persiana LXXVIII de Montesquieu, ed. G. Mercadier, Université de Toulouse, France-Iberie Recherche, 1970.

${ }^{10}$ Ibid., p. 21.

${ }^{11}$ J. de Cadalso, Cartas marruecas. Prólogo, edición y notas de L. Dupuis y N. Glendinining, London, Tamesis Books Limited, 1966, Prólogo, pp. XVIII-XIX.

${ }^{12}$ Compárese lo dicho por D. Hume en la conclusión del Tratado de la naturaleza humana. Ed. de F. Duque. Madrid. Tecnos, 2005, III, III, VI, §618, p. 818: "la felicidad de las personas ajenas nos afecta únicamente por simpatía. Luego será a este principio al que tendremos que atribuir el sentimiento de aprobación, que surge del examen de toda virtud útil a la sociedad o a la persona 
Existen, además, infinidad de artículos que se centran en el pensamiento de Cadalso y, al hilo de ello, mencionan la relación entre su obra y las Cartas persas de Montesquieu; la atención específica al asunto que nos ocupa apenas aparece en ninguno de ellos ${ }^{13}$.

Por último, debo señalar que no han sido pocos los estudios dedicados a la conquista de América en Cadalso ${ }^{14}$. Algunos de ellos pagan el obligado tributo de mencionar a Montesquieu, pero ninguno ha hecho de la comparación entre ambos autores el objeto particular de su análisis.

Antes de iniciar este, conviene señalar que solo tendré en cuenta las obras publicadas por Montesquieu, únicas a las que pudo tener acceso Cadalso. Dejaré de lado, por tanto, las numerosas referencias que aparecen en las Considérations sur les richesses de l'Espagne, en las Réflexions sur la monarchie uniuerselle, en Mes pensées, etc., no sin recordar que Montesquieu utilizó estos escritos en

poseedora de dicha virtud. Además, estas virtudes constituyen la parte más importante de la moral", con esta afirmación de Cadalso, Cartas marruecas. Noches lúgubres, ed. R. P. Sebold, Madrid, Cátedra, 20066; en lo sucesivo, citaremos ambas obras por esta edición: Cartas marruecas LXX, p. 314: "El gustar de su semejante es calidad que días ha se ha descubierto propia de nuestra naturaleza, pero con más fuerza entre los buenos que entre los malvados; o, por mejor decir, sólo entre los buenos se halla esta simpatía, pues los malos se miran siempre unos a otros con notable recelo, y si se tratan con aparente intimidad sus corazones están siempre tan separados como estrechados sus brazos y apretadas sus manos".

${ }^{13}$ Quizá habría que mencionar como excepción el artículo de F. Lopez, "La stratégie des Cartas marruecas", en C. Serrano, J.-P. Duviols y A. Molinié, eds., Les voies des Lumières. Le monde ibérique au XVIIIe siècle, Presses de l'Université de Paris-Sorbonne, 1998, pp. 67-78, que, aunque se ocupa poco de la cuestión americana, lo hace en un marco comparativo que sobrepasa su artículo de título más comprometido "De las Lettres persanes a las Cartas marruecas", en J.-P. Sánchez, coord., Ville et campagne en Espagne au XVIIIe. Siècle, Paris, Éditions du Temps, 1997, pp. 174-90, reproducción casi íntegra de su "Cadalso y la cuestión nacional”, Coloquio Internacional sobre José Cadalso. Bolonia, 26-29 de Octubre de 1982, Albano Terme, Piovan Editore, 1985, pp. 235-55. Dos comparaciones dirigidas a cuestiones concretas, que tampoco entran en la cuestión de la conquista, son las realizadas por A. Domínguez, "Las Lettres persanes y las Cartas marruecas: la función de la perspectiva en la crítica social de dos novelas epistolares”, en F. Lafarga (Ed.), Imágenes de Francia en las letras hispánicas, Barcelona, PPU, 1989, pp. 47-55, y por A. y Mª del M. García Marqués, "Dimensiones historiográficas de las Cartas Persas de Montesquieu y las Cartas Marruecas de Cadalso", Revista de la Facultad de Humanidades de Jaén, 2, 2, 1993, pp. 21-47. Algo similar ocurre con el libro de John B. Hughes, José Cadalso y las Cartas Marruecas, Madrid, Tecnos, 1969, cuyo quinto capítulo ("Las Cartas marruecas y las Lettres persanes"), se dedica, como dice en otro lugar de su obra (p. 46 nota), a "mostrar cuán lejos se hallaban los métodos y los fines de Cadalso de los de su modelo".

14 H.-J. Lope, “Cadalso y Hernán Cortés”, Dieciocho, 9, 1986, pp. 188-200, y ““"Pongamos la fecha desde hoy...". Historia e historiografía en las "Cartas marruecas"”, Coloquio Internacional sobre José Cadalso, op. cit., pp. 211-33; R. Froldi, "La conquista dell'America e Cadalso", edición digital a partir de la separata de Studi di Iberistica in memoria di Alberto Boscoso, Roma, Bulzoni, 1989, pp. 113-27, consultado 10.XII.2008, accesible en http://www.cervantesvirtual.com/servlet/ SirveObras/23586286543403851965679/index.htm; J. Yagüe Bosch, "Defensa de España y conquista de América en el siglo XVIII: Cadalso y Forner", Dieciocho, 28, I, 2005, pp. 121-40; X. Andreu Miralles, "¿"Razón crítica" vs. "sentimiento patriótico”?: Cadalso y el carácter nacional”, en M" E. Nicolás Marín y C. González Martínez, coords., Ayeres en discusión: temas clave de Historia Contemporánea hoy, recurso electrónico, 2009; consultado 20.XII.2012, accesible en http://www. ahistcon.org/docs/murcia/contenido/pdf/08/xavier_andreu_miralles_taller08.pdf.

Araucaria. Revista Iberoamericana de Filosofía, Política, Humanidades y Relaciones Internacionales, año 20, $\mathrm{n}^{\circ} 40$. Segundo semestre de 2018. Pp. 75-107. ISSN 1575-6823 e-ISSN 2340-2199 doi: 10.12795/araucaria.2018.i40.04 
sus obras publicadas ${ }^{15}$, y que el tratamiento que dedica a España en las mismas es más imparcial que el que lleva a cabo en aquellas ${ }^{16}$. Hay que aceptar, por otra parte, que el señor de la Brède pudo utilizar el modelo español como experimento para ver las consecuencias económicas del dominio colonial ${ }^{17}$, pero, a pesar de sus críticas por la crueldad, la destrucción y el expolio derivados de la dominación, fundamentalmente española o ibérica, de otras sociedades, $\mathrm{y}$ de los efectos perniciosos que provocaba en el interior de las naciones europeas y en sus relaciones mutuas, no renunció al colonialismo ${ }^{18}$. Tampoco supo apreciar la importancia de los aparatos administrativos creados por las monarquías absolutas para el proceso de formación y de reforzamiento de los Estados modernos ${ }^{19}$; esto último dificultó, entre otras cosas, su comprensión de la realidad hispana, sobre la que no le faltaba información de primera mano ${ }^{20}$.

\section{Problemas materiales derivados de la conquista de América}

Tras una estancia en el Colegio de los jesuitas de Cádiz, donde enseñaba su tío, la educación cosmopolita de Cadalso se había forjado durante más de cuatro años en el parisino Collège de Louis-le-Grand, completados por casi dos años más de estudio en Londres y sus alrededores. Vuelve de allí a "un país que era totalmente extraño para mí, aunque era mi patria. Lengua, costumbres, traje, todo era nuevo para un muchacho que había salido niño de España, y volvía a ella con todo el desenfreno de un francés, y toda la aspereza de un inglés" ${ }^{21}$. Su posterior enseñanza en el prestigioso Real Seminario de Nobles de Madrid debió de acabar de familiarizarle con la tradición

${ }^{15}$ Montesquieu, Del espiritu de las leyes, trad. de M. Blázquez y P. de Vega, prólogo de E. Tierno Galván, Madrid, Tecnos, 1980; libro XXI, cap. XXII, p. 302, nota (que se citará en lo sucesivo): "Esto [el contenido del capítulo] apareció hace más de veinte años, en un pequeño libro manuscrito del autor [Considérations], que fue luego fundido casi enteramente en éste".

${ }^{16}$ G. Barrera, 'La figure de l'Espagne dans l'oeuvre de Montesquieu: élaboration conceptuelle d'un exemple, stratégie d'écriture et mode d'avertissement", Actes du Colloque international de Bordeaux 1998, Académie de Bordeaux, 1999, pp. 153-71 (164) ; F. Étienvre, "Montesquieu y Voltaire: sus visiones de España", en J. Checa Beltrán (Ed.), Lecturas del legado español en la Europa ilustrada. Madrid. Iberoamericana Vervuert, 2012, pp. 67-103.

17 J.-M. Goulemot, “L’Espagne de Montesquieu”, Bulletin de la Société Montesquieu, 7, 1995, pp. 16-26 (25).

${ }^{18}$ F. Castilla Urbano, "Conquista y comercio: la visión colonial de Montesquieu”, en F. Castilla Urbano (Editor), Visiones de la conquista y la colonización de las Américas. Universidad de Alcalá, 2015, pp. 89-106.

19 D. Felice, "Francia, Spagna e Portogallo: le monarchie europee "qui vont au despotisme" secondo Montesquieu”, Cahiers Montesquieu, 2, 1995, p. 283-305 (p. 304).

${ }^{20}$ G. Barrera, "Espagne", Dictionnaire électronique Montesquieu [En ligne], mis à jour le: 13/02/2008, URL: http://w7.ens-lsh.fr/dictionnaire-montesquieu/index.php?id=321 (Consulta 1.VI.2013). Véase, en la misma dirección, los interesantes artículos del autor dedicados a las "Colonies" y a las "Amériques".

${ }^{21}$ J. de Cadalso, Escritos autobiográficos y epistolario, ed. N. Glendinning y N. Harrison, London, Tamesis Books Limited, 1979, "Memoria de los acontecimientos más particulares de mi vida", p. 7. 
española sin impedirle numerosas lecturas de autores franceses y británicos contemporáneos, como han constatado bastantes estudios ${ }^{22}$. Uno de los más destacados, sino el que más, tanto por las citas expresas que realiza en sus obras como por las referencias que se pueden localizar en las mismas es, sin duda, Montesquieu. La admiración y algún que otro reproche hacia el Presidente del Parlamento bordelés se mezclan en sus textos, especialmente en los que tienen que ver con la conquista española de América. En relación con esta, Cadalso no rehúye el compromiso al expresar con detalle su opinión, aunque esta dista de ser unilateral y revela no sólo sentimientos encontrados sino una compleja valoración ${ }^{23}$. No en vano, como señala Nuño Núñez, el alter ego de Cadalso en las Cartas marruecas ${ }^{24}$, "era asunto dignísimo de un fino discernimiento, juiciosa crítica y madura reflexión" 25 .

Será, precisamente en esta obra, donde más espacio dedique Cadalso al análisis de la realidad americana, y en la que presenta el destino de aquel continente ligado a la historia de España:

\begin{abstract}
"Supuesto que la conquista y dominio de aquel medio mundo tuvieron y aún tienen tanto influjo sobre las costumbres de los españoles, que son ahora el objeto de mi especulación, la lectura de esta historia particular es un suplemento necesario al de la historia general de España, y clave precisa para la inteligencia de varias alteraciones sucedidas en el estado político y moral de esta nación"26.
\end{abstract}

Este planteamiento, la vinculación de lo español y lo americano, está muy arraigado en Cadalso, que lo repite en un tono satírico, poniéndolo en boca de un petimetre, por la misma época en la que debía estar redactando las Cartas marruecas, en el Suplemento al papel intitulado Los eruditos a la violeta:

"ni sé hasta dónde llega la memoria de la población de España, ni en qué tiempo ha sido conquistada, ni conquistadora, qué familias han reynado en

${ }^{22}$ Además de los ya citados, F. Bermúdez-Cañete, "Cadalso en su contexto europeo", Cuadernos Hispanoamericanos, CXXX, 389, 1982, pp. 263-78; K. Reding, "A study of the influence of Oliver Goldsmith's Citizen of the World upon the Cartas marruecas of José Cadalso", Hispanic Review, 2, 3, 1934, pp. 226-34; M. Raimondi Capasso, "Cadalso et Rousseau", Acme: Annali della Facoltà di lettere e filosofia dell'Università degli studi di Milano, 20, 1967, pp. 97-116, etc.

${ }^{23}$ F. Castilla Urbano, "La conquista y colonización de América en Cadalso: entre el patriotismo y la Ilustración”, Revista de Estudios Políticos, 167 (2015), pp. 33-57.

${ }^{24}$ M. Fabbri, "Don José Cadalso relator de las "Cartas marruecas"”, Coloquio Internacional sobre José Cadalso, op. cit., p. 130: "Ben-Beley, Gazel, Nuño son tres aspectos especulares de un mismo pensamiento, proyecciones heteronómicas de Cadalso con paridad de significado. Por consiguiente, para comprender plenamente la ideología y el sentir de Cadalso, es necesario unificar las tres imágenes que las Cartas ofrecen”. Esta consideración no puede ignorar la primacía intelectual de Nuño sobre los otros dos protagonistas de las Cartas; véase John B. Hughes, op. cit., p. 69: "La imaginación creadora de Cadalso, como hombre y como escritor, logra expresión auténtica, aunque breve, en la figura de Nuño".

${ }^{25}$ Cartas marruecas IX, p. 182.

${ }^{26}$ Ibid., V, p. 167.

Araucaria. Revista Iberoamericana de Filosofia, Política, Humanidades y Relaciones Internacionales, año 20, ${ }^{\circ} 40$. Segundo semestre de 2018. Pp. 75-107. ISSN 1575-6823 e-ISSN 2340-2199 doi: 10.12795/araucaria.2018.i40.04 
estos Tronos, en quántas coronas ha sido dividida, quándo se reunieron, quién descubrió las Américas, quiénes las conquistaron, en qué Reynados se hizo la conquista, qué ventaja, ò perjuicios ha causado la agregación de tanto dominio à esta Península, qué influjo tuvo sobre las costumbres españolas la abundancia americana, qué uso podemos hacer de ellas, ni de nuestras posesiones en el mar del Asia"27.

No sería exagerado ver en esta afirmación reiterada una alusión a la visión que el propio Montesquieu tiene no sólo de la historia de España, sino de la misma España, a la que, sin dejar de reconocer que tiene, como Francia, un tamaño ideal como monarquía europea para su defensa ${ }^{28}$, concibe también ligada a América; sin embargo, Montesquieu, haciendo uso de una perspectiva en la que parece primar la extensión territorial, estima que es esta la que desempeña el papel principal: "Las Indias y España son dos potencias bajo un mismo dueño; pero las Indias son la principal, España no es sino accesoria. En vano la política quiere hacer principal lo accesorio: las Indias atraen siempre a España hacia sí"'29.

La aparente contradicción no es sino coincidencia en la visión que ambos tienen de las relaciones España-América, puesto que lo señalado por Cadalso no es que España sea más importante que América, sino que al ser objeto de su análisis pasa a un primer plano la historia de la Península pero reconociendo que no se puede entender ésta sin la del Nuevo Mundo. Por tanto, a través de Cadalso y de Montesquieu, queda claro que América y España han ido y van de la mano. La comprensión de una requiere tener en cuenta a la otra.

Lo interesante es que ambos autores ven en esa relación la clave del proceso de decadencia por el que consideran que atraviesa España. En los dos, la conquista de América resulta ser el punto de partida del proceso: se inicia con las mejores perspectivas para los descubridores, hasta permitir a sus monarcas, considera Cadalso, competir en grandeza con la Roma imperial: los Reyes Católicos "se pudieron haber lisonjeado de dejar a sus sucesores un imperio mayor y más duradero que el de la Roma antigua (contando las Américas nuevamente descubiertas)" ${ }^{\prime 30}$.

27 J. Vázquez (seudónimo de J. Cadalso), Suplemento al papel intitulado Los eruditos a la violeta, reproducción de la edición de Madrid, Sancha, 1772, Sevilla, Ediciones Alfar, 1983, p. 70.

${ }^{28}$ Del espiritu de las leyes IX, VI, pp. 137-38: "Francia y España tiene precisamente la extensión requerida. Las fuerzas se comunican tan bien, que se trasladan a donde se quiera; los Ejércitos se reúnen rápidamente de una a otra frontera y no hay que temer ninguna empresa cuya ejecución necesite cierto tiempo".

${ }^{29}$ Ibídem XXI, XXII, pp. 304-305; para los antecedentes de esta visión en W. Paterson, P. Fernández Albadalejo, "Entre la "gravedad" y la "religión": Montesquieu y la "tutela" de la Monarquía católica en el primer setecientos”, en A. Mestre, P. Fernández Albaladejo y E. Giménez López, coords., Monarquí, imperio y pueblos en la España moderna (V. I). Actas de la IV Reunión Científica de la Asociación Española de Historia Moderna Alicante, 27-30 de mayo de 1996, 1997, pp. 3-24 (8-9).

${ }^{30}$ Cartas Marruecas III, p. 159; véase XVI, p. 202. 
Esta comparación entre la Monarquía Hispánica y Roma es también una constante del pensamiento de Montesquieu, como muestran sus Consideraciones sobre las causas de la grandeza y decadencia de los romanos de manera explícita, pero igualmente múltiples manifestaciones presentes en todas sus obras ${ }^{31}$.

También aparece en el pensamiento de Cadalso otro elemento que provocó numerosas reflexiones de Montesquieu: cómo esa grandeza inicial de España, que se asienta sobre la adquisición de enormes riquezas y el dominio de ingentes territorios, acaba conduciendo a la ruina moral y material de los españoles. Este proceso no es exclusivo del Imperio español. Montesquieu cree que se extiende a todos los que han existido ${ }^{32}$; quizá, en el caso de España, lo que sorprende es la rapidez con la que se alcanza y el tamaño de lo conseguido ${ }^{33}$. Tal vez porque los dominios americanos sufren la sospecha de una insuficiencia constitucional, de un carácter defectivo que les es inherente, los indios americanos, lejos de ser descritos según el modelo del "buen salvaje" que comparten tantos ilustrados, son presentados como individuos dados a los peores vicios: "decid los bárbaros sacrificios que hacían los mejicanos a su ídolo con víctimas humanas", dice el maestro a sus eruditos violetos ${ }^{34}$. Los aludidos son los mismos que se muestran incapaces de sacar provecho de los recursos que poseen:

“¡Extraña suerte es la de la América! ¡Parece que está destinada a no producir jamás el menor beneficio a sus poseedores! Antes de la llegada de los europeos, sus habitantes comían carne humana, andaban desnudos, y los dueños de la mayor parte de la plata y oro del orbe no tenían la menor comodidad de la vida. Después de su conquista, sus nuevos dueños, los españoles, son los que menos aprovechan aquella abundancia" ${ }^{35}$.

Esta visión de Cadalso es compartida por Montesquieu, que, por una parte y según la complejidad de su organización política, aprecia en los habitantes de América una situación de salvajismo o de despotismo: "en América los imperios despóticos de Méjico y Perú estaban localizados en los trópicos,

${ }^{31}$ P. Barriére, "Montesquieu et 1'Espagne", Bulletin Hispanique, 49, 3-4, 1947, pp. 299-310 (300301); L. Díez del Corral, El pensamiento político europeo y la monarquía de España, Madrid, Alianza Ed., 1983 (1975), pp. 449-63.

32 Montesquieu, Consideraciones sobre las causas de la grandeza y decadencia de los romanos. Tarragona. Imprenta de M. Puigrubi, 1835 (1734), p. 14: "Si [los romanos] hubiesen conquistado rápidamente todos los pueblos vecinos, se habrían hallado en decadencia cuando se les presentaron Pirro, los galos, y Aníbal; y conforme al destino de casi todas las naciones del mundo, habrían pasado con demasiada prontitud, de la pobreza a las riquezas, y de estas a la corrupción".

${ }^{33}$ Montesquieu, Cartas persas, trad. de J. Marchena, estudio preliminar de J. M. Colomer, Madrid, Tecnos, 1986 (1721), carta CXXI.

34 J. Vázquez (seudónimo de J. Cadalso), Los eruditos a la violeta, reproducción de la edición de Madrid, Sancha, 1772, con introducción de M. Á. Vázquez Medel, Madrid, Ediciones Alfar, 1982, p. 47.

35 Cartas Marruecas XLI, p. 248.

Araucaria. Revista Iberoamericana de Filosofia, Política, Humanidades y Relaciones Internacionales, año 20, $\mathrm{n}^{\circ} 40$. Segundo semestre de 2018. Pp. 75-107. ISSN 1575-6823 e-ISSN 2340-2199 doi: 10.12795/araucaria.2018.i40.04 
mientras que casi todos los pequeños pueblos libres habitaban y habitan aún hacia los Polos" "36; por otra parte, ve en la conquista no sólo la ruina del Nuevo Mundo, sino la de los mismos españoles:

\begin{abstract}
"Si Europa encontró tantas ventajas en el comercio de América, sería natural creer que España las hubiese encontrado mayores, ya que sacó del mundo recientemente descubierto una cantidad tan prodigiosa de oro y de plata, que no podía compararse con la cantidad total de que se disponía hasta entonces.

"Pero (cosa que nunca se hubiera sospechado) la miseria la hizo fracasar en todas partes. Felipe II, sucesor de Carlos V, se vio obligado a hacer la célebre bancarrota conocida por todos; nunca hubo príncipe que haya sufrido más de las murmuraciones, la insolencia y la sublevación de sus tropas, siempre mal pagadas.

"Desde entonces, la Monarquía española fue declinando continuamente: había un vicio interior y físico en la naturaleza de aquellas riquezas, que las hacía vanas, y este vicio crecía de día en día" ${ }^{37}$.
\end{abstract}

La valoración utilitaria de la conquista, tan característica de los ilustrados, se impone sobre las consideraciones religiosas o de gloria que hayan podido esgrimir otras épocas. El problema es que la acumulación de metales preciosos no constituye un auténtico beneficio económico y dirige a España a la ruina económica. El mensaje evangelizador, que sirvió de soporte ideológico en los siglos anteriores e incluso dio para que un conquistador como Cortés apuntalara alguna victoria en circunstancias difíciles ${ }^{38}$, tampoco se mantiene: Gazel, el protagonista moro de las Cartas Marruecas, se lo atribuye a "los españoles", pero no es asumido por Nuño, consciente de su inadecuación al tiempo en que vive $^{39}$. Tal vez por ello, no le resulta difícil excluir de la tutela espiritual la justificación del descubrimiento y la conquista de América apelando a que una historia de estas características formaría un género "para el pueblo, en la que hubiese efectivamente caballos llenos de hombres y armas, dioses amigos y contrarios, y sucesos maravillosos" ${ }^{40}$.

${ }^{36}$ Del espíritu de las leyes XVII, II, p. 229; estos “pequeños pueblos libres” son considerados salvajes apegados a un modo de vida cazador en las Cartas persas CXX.

37 Ibid., XXI, XXII, pp. 302-303.

${ }^{38}$ Cortés, dirigido por la Providencia (Cartas Marruecas IX, p. 183), vio "a sus soldados obrar portentos de un valor verdaderamente más que humano, porque sus ejércitos vieron o creyeron ver la misma aparición" [de Santiago] (Ibid., LXXXVII, p. 351).

${ }^{39}$ Ibid., IX, p. 181: “del lado de los españoles no se oye [para explicar la conquista de América] sino religión, heroísmo, vasallaje y otras voces dignas de respeto".

40 Ibid., LIX, p. 280; véase la irónica carta 38 a Tomás de Iriarte (febrero de 1774), en J. de Cadalso, Escritos autobiográficos y epistolario, p. 78: “Por qué tengo yo que poner en tela de juicio lo que otros bien podían juzgar por sí mismos, sobre la cuestión de la justicia y adecuación de la plumbaria bula que el Papa Alejandro VI otorgó, confiando a Fernando V e Isabel, llamados católicos por su religiosidad ejemplar, la tarea de someter a estos indios al imperio hispánico, forzándolos a convertirse a la fe de Cristo? Nosotros, como nuestros antepasados, procuramos proceder conforme a nuestros principios, no sólo en cuanto a las palabras sino también en las obras hechas en la guerra de las Indias, actuando como convenía a tan católicos monarcas".

Araucaria. Revista Iberoamericana de Filosofia, Política, Humanidades y Relaciones Internacionales, año 20, $\mathrm{n}^{\circ} 40$ Segundo semestre de 2018. Pp. 75-107. ISSN 1575-6823 e-ISSN 2340-2199 doi: 10.12795/araucaria.2018.i40.04 
El Cadalso más maduro parece identificarse claramente con esta postura; en el que tal vez sea el primero de sus escritos, se declara "católico"41, pero con posterioridad, acaso por efecto de la relajación de la fe con el paso del tiempo ${ }^{42}$, no reniega de un uso instrumental de la creencia religiosa: "En fin, ninguna nación guerrera puede tener la menor ventaja en una campaña, que no se la igualen los enemigos en la siguiente. Pero la creencia de que baja un campeón celeste a auxiliar a una tropa, la llena de un vigor inimitable"43.

También a este respecto, hay que recordar que Montesquieu fue mucho más allá al ver en la religión (católica) un instrumento de dominio, que proporcionaba justificación psicológica a los conquistadores de América:

"Diría también que la religión otorga a los que la profesan el derecho de reducir a esclavitud a los que no la profesan, para trabajar más fácilmente en su propagación. Esta manera de pensar estimuló a los destructores de América en sus crímenes. En esta idea fundaron el derecho de esclavizar a tantos pueblos, pues aquellos bandidos que querían ser de todos modos bandidos y cristianos, eran muy devotos" $" 44$.

A pesar de ello, su rechazo del despotismo era, si cabe, todavía mayor, por lo que no dejó de encontrar en la influencia clerical sobre los monarcas un poder intermedio útil para amortiguar el avance de aquel en España:

"El poder del clero es tan peligroso en una república, como conveniente en una monarquía, sobre todo en las que van hacia el despotismo. ¿Qué sería de España y de Portugal desde el momento en que perdieron sus leyes, si no fuera por esta potencia, la única que contiene al poder arbitrario? Cuando no hay otra, ésta es siempre buena, pues como el despotismo causa a la naturaleza humana daños terribles, aquello que la limita será bueno, aunque en sí sea malo"45.

La religión, por tanto, no puede justificar lo ocurrido en el Nuevo Mundo, aunque resulte útil para multiplicar el ardor militar de los conquistadores o para templar la tendencia al despotismo del país. A Cadalso, sin embargo, le sirve también para matizar otra de las acusaciones de Montesquieu sobre los españoles: su orgullo, vanidad y soberbia ${ }^{46}$. Cadalso rebaja el volumen de la acusación en la Defensa de la nación española: "Conozco que en nuestro carácter nacional se halla alguna soberbia", pero intenta mostrar que no puede

${ }^{41}$ Defensa de la nación española, p. 5.

42 N. Glendinning, "Ideas políticas y religiosas de Cadalso", Cuadernos Hispanoamericanos, 389, 2, 1982, pp. 247-62, y, sobre todo, J. Demerson, "Cadalso, la Religión y la Iglesia”, en J. Amor y Vázquez y A. D. Kossoff, eds., Homenaje a Juan López-Morillas. De Cadalso a Aleixandre: Estudios sobre literatura e historia intelectual españolas, Madrid, Castalia, 1982, pp. 151-69.

43 Cartas Marruecas LXXXVII, p. 352.

${ }^{44}$ Del espiritu de las leyes XV, IV, p. 210.

45 Ibid., II, IV, p. 61.

${ }^{46}$ Cartas persas LXXVIII, p. 115-16; Del espiritu de las leyes XIX, IX, p. 250. 
ser tanta contraponiéndola a otra acusación del barón, la del excesivo pundonor: "No hay que extrañarse de que el conde Julián creyese que un ultraje de esta clase exigía la pérdida de su patria y de su rey" 47 . En realidad, "Si el conde don Julián hubiera tenido un poco de vanidad, no hubiera vendido su patria a los moros por vengar su ofensa particular" ${ }^{48}$, de manera que Montesquieu se equivoca en una de las dos imputaciones, si no en ambas.

También en las Cartas marruecas se admiten la vanidad y la pereza como propias del carácter nacional ${ }^{49}$, pero se matiza a continuación; por una parte, se acepta que existe el orgullo pero en forma inversamente proporcional a la importancia real de las personas: nada en los reyes y su familia, que muestran su humildad lavando los pies de los pobres en algunos días señalados; poco en los más nobles, que se identifican con sus criados y algo más según se desciende a la nobleza menos elevada, los hidalgos y, sobre todo, a los mendigos ${ }^{50}$. Por otra parte, se interpreta la costumbre de atribuir a Santiago la intervención en batallas como un rasgo de humildad, quitándose importancia los mismos que han participado en ellas para otorgársela al santo, "lo cual contradice la vanidad y orgullo que nos atribuyen los extraños" 51 .

A falta de religión, sólo queda la rentabilidad como argumento dieciochesco inevitable a propósito de las Indias ${ }^{52}$. Pero, como se ha dicho, presenta una cara amarga. Las riquezas de las colonias no sólo no han favorecido a la metrópoli ${ }^{53}$, sino que han precipitado su rechazo por el resto de Europa: "Los tesoros, victorias y otras ventajas que nacieron de tanta felicidad la hicieron temer y, de allí a poco, aborrecer de toda Europa"54; este mismo diagnóstico, basado en el temor que provoca un poder excesivo, está presente en Montesquieu, que lo aplica a Luis XIV:

"Los enemigos de un gran príncipe que reinó durante mucho tiempo le acusaron mil veces, más bien, según creo, guiados por sus temores que por sus razones, de haber concebido e intentado el proyecto de Monarquía universal. Si lo hubiera conseguido, nada habría sido tan fatal para Europa, para sus antiguos súbditos, para él y para su familia. El cielo, que conoce las verdaderas ventajas, le fue más propicio dándole derrotas que proporcionándole victorias. En lugar de convertirle en el único rey de Europa le favoreció más haciéndole el más poderoso" $" 55$.

${ }^{47}$ Del espiritu de las leyes XIV, XIV, p. 207.

${ }^{48}$ Defensa de la nación española, p. 18.

${ }^{49}$ Cartas marruecas XXI.

${ }^{50}$ Ibid., XXXVIII, pp. 241-43; véase ibidem, III, p. 160.

${ }^{51}$ Ibid., LXXXVII, p. 351.

${ }^{52}$ Ibid., LXXIV, p. 320.

${ }^{53}$ Ibid., XLIV, p. 253.

${ }^{54}$ Defensa de la nación española, pp. 8-9.

${ }^{55}$ Del espiritu de las leyes IX, VII, p. 138.

Araucaria. Revista Iberoamericana de Filosofia, Politica, Humanidades y Relaciones Internacionales, año 20, ${ }^{\circ} 40$. Segundo semestre de 2018. Pp. 75-107. ISSN 1575-6823 e-ISSN 2340-2199 doi: 10.12795/araucaria.2018.i40.04 
La España filipina no tuvo la suerte que el ilustrado francés aprecia en la derrota de los proyectos de conquista del Rey Sol. Cadalso atribuye su decadencia posterior a las continuas guerras, a los tesoros americanos que las financian y, cómo no, de nuevo la sombra de la Brède, a la disminución de la población que provoca el Nuevo Mundo; todo ello propicia el hundimiento de la industria peninsular e impide incrementar la población ${ }^{56}$; esto último, que es una constante del pensamiento de Cadalso, sabemos hoy que es un error ${ }^{57}$, pero es llevado al mismo por el propio Montesquieu, que lo predica para todos los países colonialistas, pero especialmente para España ${ }^{58}$. En una senda que sigue la mayor parte de los ilustrados españoles ${ }^{59}$, señala que la conquista destruyó las poblaciones indias ${ }^{60}$ y las redujo a esclavitud ${ }^{61}$; el resultado fue la ruina de lo que hasta entonces era un país próspero: las grandes cantidades de oro y plata extraídas de América generan inflación en España, pierden valor constantemente y benefician a la industria y el comercio europeo y mundial ${ }^{62}$.

La insistencia de Montesquieu, expresada muy tempranamente en las Cartas persas $^{63}$ y confirmada en El espíritu de las leyes ${ }^{64}$, de que la población del mundo está disminuyendo, no sólo encuentra en España y las Indias una confirmación $^{65}$, sino que la enfermedad se ve agravada en ambos casos por el vínculo que las mantiene unidas: "Común efecto es de las colonias enflaquecer los países de donde se sacan sin poblar aquellos adonde se envían" ${ }^{\text {" No }}$. han conseguido paliar esta situación ni los esclavos negros ni los habitantes de la metrópoli, ella misma enferma del mal que ha provocado: "Desde que los españoles, habiendo asolado América exterminaron a sus antiguos moradores sustituyéndose en su lugar, no han podido repoblarla; y muy al contrario, por

${ }^{56}$ Cartas marruecas III, p. 160. La falta de fábricas propias, que obliga a distribuir el oro y la plata americanos por Europa (XLI, pp. 247-48) y, todavía más, la "continua extracción de hombres para las Américas" (XXXIV, p. 232).

${ }_{57}$ Aunque acierta al afirmar que en su tiempo España tenía aproximadamente diez millones de habitantes, no es cierto que sean la "mitad del número de vasallos españoles que contaba Fernando el Católico" (Cartas marruecas IV); véanse las notas 18 (p. 21) y 21.18 (p. 314) de E. Martínez Mata a su edición de J. de Cadalso, Cartas marruecas. Noches lúgubres, Barcelona, Crítica, 2000.

58 Cartas persas CXXI.

59 R. Ezquerra, "La crítica española de la situación de América en el siglo XVIII", Revista de Indias, 22, 1962, pp. 159-287 (278); M. Artola, "América en el pensamiento español del siglo XVIII", Revista de Indias, 29, 1969, pp. 51-77 (67); J. Yagüe Bosch, “Aspectos de la visión de América en los ilustrados", Cauce, 14-15, 1992, pp. 639-68 (647-51).

${ }^{60}$ Del espíritu de las leyes VIII, XVIII, p. 132: España "Para conservar América hizo lo que no hace ni siquiera el despotismo: destruyó a sus habitantes. Para conservar sus colonias tuvo que ponerlas bajo la dependencia de su propia subsistencia".

${ }^{61}$ Cartas persas $\mathrm{CV}$.

${ }^{62}$ Del espíritu de las leyes XXI, XXII, pp. 302-305; véase ibídem, XXII, V y VI.

${ }^{63}$ Cartas persas CXII, p. 159: “¿Cómo está la tierra tan poco poblada, relativamente a lo que antes estaba? ¿Cómo ha podido perder la naturaleza la portentosa fecundidad de los primitivos tiempos? ¿Acaso está ya decrépita y se muere de inanición?”.

${ }^{64}$ Del espiritu de las leyes XXIII.

${ }^{65}$ Cartas persas CXII, p. 160.

${ }^{66}$ Ibid., CXXI, p. 172.

Araucaria. Revista Iberoamericana de Filosofia, Política, Humanidades y Relaciones Internacionales, año $20, \mathrm{n}^{\circ} 40$. Segundo semestre de 2018. Pp. 75-107. ISSN 1575-6823 e-ISSN 2340-2199 doi: 10.12795/araucaria.2018.i40.04 
una fatalidad que pudiera más bien llamarse justicia de Dios, se destruyen los destructores a sí mismos y se consumen todos los días"67. Montesquieu sólo halla un remedio para superar esa situación, opción sobre la que Cadalso no se pronuncia:

\begin{abstract}
"Me atrevo a decir que en vez de que pasaran los españoles a las Indias, convendría hacer que pasaran los indios y los mestizos a España, convendría restituir a esta monarquía todos sus pueblos dispersos; $\mathrm{y}$, con tal que conservara sólo la mitad de sus vastas colonias, sería la más formidable potencia de Europa" ${ }^{68}$.
\end{abstract}

En ese contexto, de nada sirve la aptitud para la guerra mostrada por los españoles. Todas las riquezas ganadas se han perdido en lo que reclama la guerra misma, sin alcanzar a poseer lo que hace dichosos a los hombres y verdaderamente poderosas a las naciones:

\begin{abstract}
"Grandes armadas, numerosos ejércitos, sumas considerables, con poco o ningún fruto y con mucho menoscabo de la población, la dejaron en breve exhausta de todos aquellos artículos que constituyen la verdadera felicidad de una nación. Todos los españoles eran soldados, y excelentes soldados. Pero un pueblo compuesto de guerreros jamás será feliz, pues le faltan labradores, comerciantes, sabios y otras clases que suavizan al género humano y le hacen hallar su verdadero bien en la sociedad humana y comercio" ${ }^{69}$.
\end{abstract}

Como puede apreciarse, Cadalso, en un juego dialéctico que tal vez deba ponerse en relación con la censura pero que tiene su antecedente, quizá por la misma causa, en el mismo Montesquieu ${ }^{70}$, no sólo se salta su manifiesta determinación de mantenerse al margen de enjuiciar la utilidad de la conquista española de América ${ }^{71}$, sino que asume la opinión del señor de la

${ }^{67}$ Ibid., p. 173

${ }^{68}$ Ibid., p. 174.

${ }^{69}$ Defensa de la nación española, p. 9. La actitud ante la guerra de Cadalso también esconde cierta complejidad; véase F. Castilla Urbano, "Guerra y patriotismo en el ilustrado José Cadalso", en J. R. Cirici Narváez y A. Ramos Santana (coords.), La furia de Marte. Ideología, pensamiento y representación. XIV Encuentro de la Ilustración al Romanticismo. España, Europa y América (17501850). Universidad de Cádiz, 2012, pp. 211-27.

${ }^{70}$ Cartas persas, "Algunas reflexiones sobre las Cartas persas", p. 4: Montesquieu señala que ha mostrado a los personajes fingiendo la sorpresa inicial de alguien extraño a las costumbres europeas y lo recalca en relación a la religión, que queda excluida de la crítica: "Lejos de pensar en aludir a algún principio de nuestra religión, uno no era sospechoso ni tan sólo de imprudencia. Estos rasgos siempre están ligados al sentimiento de sorpresa y de asombro, y no a la idea de examen, y aún menos a la de crítica. Al hablar de nuestra religión, aquellos persas no debían parecer más instruidos que cuando hablaban de nuestros usos y costumbres; $y$, si alguna vez encuentran singulares nuestros dogmas, esta singularidad está siempre marcada por la huella de la perfecta ignorancia de los ligámenes que existen entre estos dogmas y nuestras demás verdades".

${ }^{71}$ Cartas marruecas V, p. 167: "No entraré en la cuestión tan vulgar de saber si estas nuevas adquisiciones han sido útiles, inútiles o perjudiciales a España. No hay evento alguno en las cosas

Araucaria. Revista Iberoamericana de Filosofia, Política, Humanidades y Relaciones Internacionales, año $20, \mathrm{n}^{\circ} 40$. Segundo semestre de 2018. Pp. 75-107. ISSN 1575-6823 e-ISSN 2340-2199 doi: 10.12795/araucaria.2018.i40.04 
Brède sobre sus consecuencias; esto, sin embargo, no le va a impedir criticar al mismo Montesquieu. El gaditano admite que la extracción de minerales no implica tanto beneficio como se le atribuye y que, por elevado que sea el precio del metal, nunca tiene el valor económico ni social de lo que produce la agricultura o lo que es fabricado o construido. Así se lo hace decir a Gazel: la posesión de unos pequeños territorios peninsulares en los que, de manera similar a otros de Europa, se fomentan la industria y las manufacturas, es más rentable que el mantenimiento de unos dominios que en su estado actual suponen una carga para la monarquía española ${ }^{72}$. Sin embargo, vuelve ese discurso claramente coincidente con las ideas del señor de la Brède ${ }^{73}$ contra este cuando subraya el enorme esfuerzo invertido en conseguirlo: "No sabe Montesquieu el trabajo que se necesita para traer algún dinero de Indias. El que trabaja en las minas, el que purifica el metal, el que lo acuña, el que lo comercia, el que lo trae a España, todos trabajan acerbamente" 74 . Responde así a la acusación de pereza que el Presidente del Parlamento de Burdeos había lanzado contra los españoles tanto en las Cartas persas ${ }^{75}$ como en El espíritu de las leyes ${ }^{76}$.

humanas que no pueda convertirse en daño o en provecho, según lo maneje la prudencia".

${ }^{72}$ Ibid., XLV, p. 256: "Por un par de provincias semejantes pudiera el rey de los cristianos trocar sus dos Américas. Más provecho redunda a su corona de la industria de estos pueblos que de la pobreza de tantos millones de indios. Si yo fuera señor de toda España y me precisaran a escoger los diferentes pueblos de ella por criados míos, haría a los catalanes mis mayordomos"; véase, no obstante, ibid., IV, p. 165: ¿¿Hablas de manufacturas? ¿Qué se han hecho las antiguas de Córdoba, Segovia y otras? Fueron famosas en el mundo, y ahora las que las han reemplazado están muy lejos de igualarlas en fama y mérito: se hallan muy en sus principios respecto a las de Francia e Inglaterra".

${ }_{73}$ Del espiritu de las leyes XXI, XXII, p. 305: "Un tributo accidental que no depende de la industria de la nación, del número de sus habitantes, ni del cultivo de la tierra, es una falsa riqueza. El rey de España, que recibe grandes sumas de su aduana en Cádiz, no es a ese respecto más que un particular muy rico en un Estado muy pobre. Todo pasa de los extranjeros a él, sin que sus súbditos participen apenas. Este comercio es independiente de la buena o de la mala fortuna de su reino. Si algunas provincias de Castilla le diesen sumas semejantes a las de la aduana de Cádiz, su poder sería mucho mayor, pues sus riquezas no podrían ser más que efecto de las riquezas del país; dichas provincias animarían a las demás, y todas juntas estarían en mejores condiciones para sostener las cargas respectivas. Y así, en lugar de un gran tesoro, habría un gran pueblo".

${ }^{74}$ Defensa de la nación española, p. 20.

${ }^{75}$ Cartas persas LXXVIII, p. 116.

${ }^{76}$ Del espiritu de las leyes XIX, IX, p. 250: "La vanidad es un estímulo para el Gobierno, tan bueno como peligroso el orgullo. Para darse cuenta de ello no hay más que recordar, por una parte, los beneficios incontables que resultan de la vanidad, como son el lujo, la industria, las artes, la moda, la cortesía y el gusto, y, por otra parte, los males infinitos que derivan del orgullo de ciertas naciones, como la pereza, la pobreza, el abandono de todo, la destrucción de las naciones que el azar ha hecho caer en sus manos, y la suya propia. La pereza es consecuencia del orgullo; el trabajo se deriva de la vanidad: el orgullo de un español le inducirá a no trabajar, mientras que la vanidad de un francés le estimulará a trabajar mejor que los demás"; véase, ibid., V, XIX, pp. 96-97 nota. 


\section{El problema moral de la conquista}

Los resultados materiales del descubrimiento y la conquista de América no son satisfactorios para España. Mucho menos lo es la polémica sobre la consideración moral de esos hechos. Las críticas por la crueldad e injusticia que guiaron la adquisición de aquellos territorios y el sometimiento de sus habitantes han crecido hasta formar parte importante de la leyenda negra; su presencia más o menos acentuada en los escritos de los philosophes va a provocar un sentimiento ambivalente en Cadalso: por una parte, es consciente de los excesos cometidos, mientras que, por otra, se siente obligado a rechazar unas críticas que también le parecen desproporcionadas. Son estas últimas las que le llevan a centrar su atención en Hernán Cortés ${ }^{77}$.

En su defensa, bastante ensalzadora, Cadalso sitúa al extremeño recorriendo una tierra desconocida, con un reducido número de seguidores y obligado a confiar sólo en sus propios recursos; se enfrenta en precarias condiciones a ejércitos mucho más numerosos, que no sólo conocen el territorio mejor que los españoles, sino que además lo dominan militarmente. El avance, la atracción y suma de aliados, los múltiples combates y el triunfo final de Cortés llevan a Cadalso a presentarle como un triunfador que supera con éxito cualquier dificultad. Rechaza tajante cualquier intento de rebajar el mérito de su victoria apelando a la barbarie de los derrotados; incluso utiliza el recurso legitimador de señalar que es capaz de poner fin a los sacrificios humanos realizados por los indios, una práctica que contradice abiertamente la imagen condescendiente que algunos ilustrados se hacen de los indígenas. El retrato cadalsiano de Cortés no elude algunas de sus acciones menos disculpables, desde su hábil desvinculación del gobernador Velázquez hasta su severidad con los españoles que se resisten a su caudillismo, desde su permanente doble juego con los indios hasta su calculado tira y afloja con la Corona española; pero Cadalso las explica siempre bajo el sesgo más favorable para el conquistador, a la vez que no deja de silenciar otras muchas (las irregularidades de su salida de Cuba, la desobediencia de las órdenes recibidas, la desafección al llegar a tierra firme, su crueldad con los indígenas, etc.) de difícil o imposible disculpa. Precisamente para conseguir ésta, en algún momento, parece conceder que la crueldad es cosa de los hombres de Cortés, pero no de su caudillo: "Estos españoles hicieron en estas conquistas las mismas hazañas que los soldados de Cortés, sin cometer

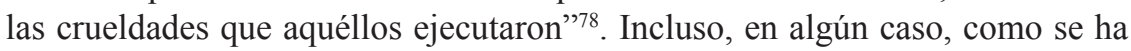
señalado ${ }^{79}$, cambia lo realmente ocurrido para justificar aún más la acción de su

${ }_{77}$ Todo lo que sigue relativo a Cortés en Cartas marruecas IX, pp. 182-88.

78 Ibid., XXXVI, p. 240.

79 Nota de L. Dupuis y N. Glendinining a su edición de J. de Cadalso, Cartas marruecas, p. 39. Atribuye a Pánfilo de Narváez el asalto al alojamiento de Cortés, cuando "en realidad Cortés atacó el campamento de Narváez".

Araucaria. Revista Iberoamericana de Filosofia, Politica, Humanidades y Relaciones Internacionales, año 20, ${ }^{\circ} 40$. Segundo semestre de 2018. Pp. 75-107. ISSN 1575-6823 e-ISSN 2340-2199 doi: 10.12795/araucaria.2018.i40.04 
héroe; sus excesos, por otra parte, son presentados como fruto de una reacción colectiva, nunca personal, de los españoles:

\begin{abstract}
"[los mejicanos] se determinan a la total aniquilación de los españoles a toda costa. De motín en motín, de traición en traición, matando a su mismo soberano, y sacrificando a sus ídolos los varios soldados de Cortés que habían caído en sus manos, ponen a los españoles en la precisión de cerrar los ojos a la humanidad; y éstos por libertar sus vidas, y en defensa propia natural de pocos más de mil contra una multitud increíble de fieras (pues en tales se habían convertido los indios), llenaron la ciudad de cadáveres, combatiendo con más mortandad de enemigos que esperanza de seguridad propia" ${ }^{\text {0 }}$.
\end{abstract}

Lo importante de esta imagen, probablemente basada en la Historia de la conquista de México de Antonio de Solís y en el capítulo 147 del Essai sur les moeurs de Voltaire, que tal vez leyó primero ${ }^{81}$, es que lo que Cadalso resalta de Cortés es la consecución de la gloria que corresponde a un héroe cívico; de ahí las cualidades que le atribuye en su relato, claramente opuesto a las valoraciones que del conquistador, de todos los conquistadores, hiciera Montesquieu $^{82}$. Para el gaditano, Cortés es un militar de férrea disciplina, valiente, afortunado en sus acciones, estadista ejemplar, incapaz de mentir en lo que afecta a su religión, sagaz y determinado ${ }^{83}$. El elogio puede extenderse, en alguna ocasión, a los soldados españoles ${ }^{84}$, pero se detiene antes de justificar la conquista americana ${ }^{85}$.

${ }^{80}$ Cartas marruecas IX, p. 187. Cursiva nuestra.

${ }^{81}$ F. Castilla Urbano, "La Historia de la conquista de México de Antonio de Solís en la obra de José Cadalso y sus fuentes francesas", en G. Franco Rubio, N. González Heras y E. de Lorenzo Álvarez (coords.), España y el continente americano en el siglo XVIII. Gijón. SEES XVIII - Ediciones Trea, 2017, pp. 827-841.

${ }^{82}$ M. C. Iglesias, "Montesquieu and Spain: Iberian Identity as Seen through the Eyes of a NonSpaniard of the Eighteenth Century", en R. Herr y J. Polt, ed., Iberian Identity: Essays on the Nature of Identity in Portugal and Spain. Berkeley. University of California. Institute of International Studies, 1989, pp. 143-55; pp. 147-148: "There is not a single page in Montesquieu's work which shows the least appreciation even of the astonishing physical feat carried out by the conquistadors; nor does his work contain the smallest semblance of a discussion of the difficulties encountered by Spain in trying to reconcile its need for rational management, arising from its status as a pioneer modern state in the world, with the ideals of an ecumenical world order almost unavoidably fostered in the political context of Europe at the dawn of the modern age".

${ }^{83}$ R. Froldi, "La conquista dell'America e Cadalso", op. cit., p. 123: "Hernán Cortés ci appare dunque come un virtuoso nel senso quasi rinascimentale e machiavellico del termine, un uomo che nell'ambito della realtà dei contemporanei si staccò da essi perché ad essi superiore".

${ }^{84}$ Cartas marruecas XLIV, p. 254: “¿quién no se envanece si se habla del siglo anterior, en que todo español era un soldado respetable? Del siglo en que nuestra armas conquistaban las dos Américas y las islas de Asia".

${ }^{85}$ H.-J. Lope, “Cadalso y Hernán Cortés”, op. cit., pp. 191-92: “Al buscar la lógica de los comentarios tan contradictorios que las Cartas marruecas ofrecen sobre Cortés y la conquista mejicana, se llega a sospechar que a Nuño le importa menos el aclarar un capítulo problemático del pasado español que el recalcar las energías extraordinarias que hacen del conquistador la personificación de una vida activa que no deja de recordar los ideales del estoicismo e incluso la filosofía de Maquiavelo, en la cual la virtus individual se opone a la ciega fortuna, es decir al azar histórico".

Araucaria. Revista Iberoamericana de Filosofia, Política, Humanidades y Relaciones Internacionales, año 20, $\mathrm{n}^{\circ} 40$. Segundo semestre de 2018. Pp. 75-107. ISSN 1575-6823 e-ISSN 2340-2199 doi: 10.12795/araucaria.2018.i40.04 
Cadalso exculpa a Cortés de cuantas acciones crueles o manipuladoras hubiera podido cometer porque lo incluye en ese grupo de hombres que sirven a la república desde la milicia, la jurisprudencia, el gobierno o las ciencias. Resucita el viejo ideal de las armas y las letras ${ }^{86}$ con el vigor de siglos pasados para expresar su esencia: quienes se entregan a esas profesiones sacrifican la propia vida, su bienestar particular y su misma hacienda "para emprender cosas grandes, y para conservar los estados" ${ }^{\prime \prime}$. Sin duda, Cadalso pensaba en Cortés cuando englobó todo ello bajo el rótulo del patriotismo:

\begin{abstract}
"El noble entusiasmo del patriotismo es el que ha guardado los estados, detenido las invasiones, asegurado las vidas, y producido aquellos hombres que son el verdadero honor del género humano. De él han dimanado las acciones heroicas imposibles de entenderse por quien no esté poseído del mismo ardor, y fáciles de imitar por quien se halla dominado por él" $" 88$.
\end{abstract}

Aun sin caer en los excesos de las naciones antiguas, que convertían a los grandes hombres en objeto de adoración, los patriotas modernos deberían gozar del reconocimiento de su país. Así lo han hecho los ingleses, pero Francia y España no han sido capaces de igualarles ${ }^{89}$. La propuesta de Cadalso para los héroes hispanos es situar sus "estatuas, monumentos y columnas... en los parajes más públicos de la villa capital con un corto elogio de cada uno, citando la historia de sus hazañas". Así no sólo se les ensalzaría, sino que se fomentaría su emulación. Cadalso no alberga duda de que, entre los varones más sobresalientes de la historia de España debería estar este "Hernán Cortés, héroe mayor que los de la fábula" ${ }^{90}$, un héroe que equipara con Alejandro o Aquiles ${ }^{91}$; su admiración le lleva incluso a ironizar sobre un galante conquistador como un "Hernán Cortés del género femenino"92.

Creo que la defensa que hace Cadalso de Cortés se corresponde con el elogio del honor que Montesquieu considera, frente a la virtud característica de las repúblicas ${ }^{93}$, que es el resorte que mueve a los hombres a realizar grandes

${ }^{86}$ Cartas marruecas LXXX, p. 338: "en nuestro siglo todo el que no lleva librea se llama don Fulano; cosa que no consiguieron in illo tempore ni Hernán Cortés, ni Sancho Dávila, ni Antonio de Leiva, ni Simón Abril, ni Luis Vives, ni Francisco Sánchez, ni los otros varones insignes en armas y letras".

${ }^{87}$ Ibid., LXX, p. 316.

88 Ibid., LXXI, p. 317.

${ }^{89}$ Ibid., XVI, pp. 200-201.

${ }^{90}$ Ibid., XVI, p. 202; véase LXXXVII, p. 351.

91 J. Vázquez (seudónimo de J. Cadalso), Los eruditos a la violeta, p. 59; se le dedican también hasta tres epitafios imaginados "para los monumentos de los principales héroes españoles", en R. Foulché-Delbosc, ed., "Obras inéditas de Don José Cadalso”, Revue Hispanique, I, 1894, pp. 258-335 (284 y 291).

92 Cartas marruecas X, p. 190.

${ }_{93}$ Del espíritu de las leyes, Advertencia del autor, p. 49.

Araucaria. Revista Iberoamericana de Filosofia, Política, Humanidades y Relaciones Internacionales, año 20, $\mathrm{n}^{\circ} 40$. Segundo semestre de 2018. Pp. 75-107. ISSN 1575-6823 e-ISSN 2340-2199 doi: 10.12795/araucaria.2018.i40.04 
acciones en las monarquías. El Barón solo habla en términos generales, por lo que no nombra a Cortés ni -con toda probabilidad- pensaría en él como hombre de honor. Pero, considera que el honor encamina a los individuos al bien común cuando creen obrar por sus intereses particulares y "puede inspirar las más hermosas acciones y, junto con la fuerza de las leyes, puede conducir al fin del gobierno [monárquico] como la misma virtud"94.

De esta índole es el patriotismo que para Cadalso es sinónimo de servicio a la sociedad y en el que se encuadraría la figura de Cortés. A un lado queda la conquista de América que, considerada como un hecho global o vista desde las actividades de otros conquistadores, no va a recibir una valoración tan favorable en sus escritos. Todo lo contrario. Si las acciones de Hernán Cortés en México son hazañas propias de un hombre excepcional, los comentarios sobre Pizarro no sólo pasan casi desapercibidos por su brevedad, sino que muestran claramente que se trata de dos casos diferentes: "En el Perú anduvieron [los españoles] menos humanos... Sí, amigo, lo confieso de buena fe, mataron muchos hombres a sangre fría" ${ }^{95}$.

En relación con este reconocimiento, no deja de ser curioso que Montesquieu hable siempre de la conquista de América criticando contundentemente a sus protagonistas: "¿A qué príncipe puede parecer envidiable la suerte de estos conquistadores? ¿Quién haría sus conquistas con las mismas condiciones?"”6; sin embargo, se explaya especialmente sobre lo ocurrido en Perú:

"Los principios que acabamos de establecer [relativos al derecho de gentes] fueron cruelmente violados por los españoles. El inca Atahualpa sólo podía ser juzgado por el derecho de gentes, pero le juzgaron por leyes políticas y civiles. Le acusaron de haber dado muerte a algunos de sus súbditos, de haber tenido muchas mujeres, etc. Y el colmo de la estupidez fue que no le condenaron por las leyes políticas y civiles de su país, sino por las leyes políticas y civiles de España"97.

Cadalso, por tanto, sólo defiende la conquista en la temprana y no editada Defensa de la nación española: "conquistar un medio mundo con un puñado de aventureros [es] hazaña gloriosísima por más que la quieran eclipsar la preocupación, envidia e ignorancia de los extranjeros empeñados

${ }^{94}$ Ibid., III, VI, p. 66 y VII, p. 67.

95 Cartas marruecas IX, p. 187. De hecho, Pizarro también recibe su epitafio elogioso, pero señalando su "crueldad [que] claman tanto los extraños" (R. Foulché-Delbosc, ed., "Obras inéditas de Don José Cadalso", op. cit., p. 285).

${ }_{96}$ Cartas persas CXXI, p. 175; recuérdese el ya citado Del espíritu de las leyes XV, IV, p. 210. Véase, además, C. Iglesias, "Montesquieu et l'Espagne", Transactions of the Seventh International Congress on the Enlightenment, Studies on Voltaire and the Eighteenth Century, CCLXIII-CCLXV, 1989, pp. 173-75 (174).

${ }^{97}$ Del espiritu de las leyes XXVI, XXII, p. 381.

Araucaria. Revista Iberoamericana de Filosofia, Política, Humanidades y Relaciones Internacionales, año $20, \mathrm{n}^{\circ} 40$ Segundo semestre de 2018. Pp. 75-107. ISSN 1575-6823 e-ISSN 2340-2199 doi: 10.12795/araucaria.2018.i40.04 
en pintarla como una serie de inhumanidades"98. Es algo excepcional, porque casi a continuación hace desaparecer esa reivindicación en el Suplemento a Los eruditos a la violeta, sustituyéndola por la enumeración de una serie de militares y conquistadores entre los que sólo Cortés y Alvarado guardan relación con América99; finalmente, pasa a considerar los excesos que acompañaron la conquista del Imperio inca. Esta opinión de Cadalso sobre la conquista y especialmente sobre lo ocurrido en Perú, se aproxima más a su crítica y, por tanto, a Montesquieu, que a los elogios de Cortés. Así lo expresan, además de las citas que venimos señalando, su correspondencia. Este último dato no debe despreciarse, puesto que en ella se manifiesta Cadalso con libertad, dirigiéndose a sus amigos y sin preocuparse de que pueda ser leído por censores o críticos. Efectivamente, la distancia entre la obra destinada al público y el texto privado nos la da la siguiente afirmación: "Extremadura produjo los conquistadores del Nuevo Mundo, y ha continuado siendo madre de insignes guerreros"100; frente a ella, es muy clara la carta que remite a Tomás de Iriarte desde Salamanca, donde se indigna contra la pretensión del claustro universitario de desentenderse de opinar sobre la conquista: "Desde que tuve uso de razón (digo rationis ratiocinantis), me ha llenado de espanto la posesión de las Américas y destrucción de unos catorce millones de almas hecha por unos cuantos extremeños"101. Es un mensaje muy similar al de otra carta de noviembre de 1774 , dirigida también a Tomás de Iriarte ${ }^{102}$. Incluso sitúa bajo sospecha el origen de la riqueza acumulada por los indianos cuando alude al "caballero que acaba de llegar de Indias con un caudal considerable (...) que fue a adquirir por varios modos a muchos millares de leguas"103. Estos comentarios muestran las dudas, si no abiertamente la crítica, hacia la conquista americana, lo que constituye una clara coincidencia con las valoraciones de Montesquieu:

\footnotetext{
“¿Qué beneficios otorgaron los españoles a los mejicanos? Pudiendo darles una religión llena de dulzura les llevaron una superstición furiosa. Pudiendo haber hecho libres a los esclavos hicieron esclavos a los hombres libres. Pudiendo instruirles sobre los abusos de los sacrificios humanos, en su lugar los exterminaron. No terminaría nunca si quisiera contar los bienes que no hicieron y los males que causaron" 104 .
}

\footnotetext{
98 Defensa de la nación española, p. 21.

99 J. Cadalso, Suplemento al papel intitulado Los eruditos a la violeta, p. 76.

${ }^{100}$ Cartas marruecas XXVI, p. 217.

101 J. Cadalso, Escritos autobiográficos y epistolario, carta de febrero de 1774, p. 79.

102 Ibid., pp. 95-96: los habitantes de Extremadura son "famosos por haber aniquilado muchos millones de semejantes suyos en otra parte de tal globulillo llamada América”.

103 Cartas marruecas XXIV, p. 213. Cursiva nuestra.

104 Del espíritu de las leyes X, IV, p. 142; Cartas persas XXI, pp. 172-175.
} 
Es evidente que hay razones más que sobradas para considerar que la opinión de Cadalso está muy lejos de la versión dulcificada de la conquista a la que alude Gazel al principio de la carta V:

\begin{abstract}
"He leído la toma de Méjico por los españoles, y un extracto de los historiadores que han escrito la conquista de esta nación en aquella remota parte del mundo que se llama América; y te aseguro que todo parece haberse ejecutado por arte mágica: descubrimiento, conquista, posesión y dominio son otras tantas maravillas" ${ }^{105}$.
\end{abstract}

\title{
4. Sospechas sobre la Ilustración europea
}

La valoración que Cadalso hace de la conquista española del Nuevo Mundo no puede ser favorable. Ni por la ausencia de moralidad que revelan los hechos ni por los resultados obtenidos cabe estar orgulloso de lo ocurrido en aquellas tierras. Sin embargo, este rechazo generalizado de la acción española en Indias, no va a impedir al gaditano rebelarse contra los que reducen al protagonismo hispano los horrores de la conquista. A sus ojos, lo que han hecho los españoles forma parte de un proceso más amplio de expansión europea; un proceso que extiende el dominio de este continente más allá de América, hasta convertirlo en la "gran fábrica de la universal dominación"106. Algo de ello deja entrever Tediato, el protagonista de las Noches lúgubres, cuando hace a Europa y no sólo a España, moralmente culpable, tanto por ser la última beneficiaria del oro americano como por ejercer un poder que no admite réplica ${ }^{107}$.

Así pues, la crítica ilustrada no debería ejercerse al margen de una mirada global en la que se desvelen no sólo los excesos hispanos, que Cadalso no niega, sino la totalidad de lo realizado por las distintas naciones europeas. Sin embargo, han sido tantas las críticas de lo hecho por los españoles, "no suenan sino codicia, tiranía, perfidia y otras no menos espantosas", que se siente legitimado para llamar la atención sobre esa cara del colonialismo dieciochesco tantas veces ignorada o silenciada:

"los pueblos que tanto vocean la crueldad de los españoles en América, son precisamente los mismos que van a las costas de África, compran animales racionales de ambos sexos a sus padres, hermanos, amigos o guerreros felices,

105 Cartas marruecas V, p. 167.

${ }^{106}$ Defensa de la nación española, p. 8.

107 J. Cadalso, Noches lúgubres, p. 373: (aludiendo a un indiano) "Tampoco vendría yo de mi casa a su tumba por todo el oro que él trajo de la infeliz América a la tirana Europa”; M. Iarocci, Properties of Modernity. Romantic Spain, Modern Europe, and the Legacies of Empire. Nashville. Vanderbilt University Press, 2006, p. 73: “And as Tediato's repeated disavowals accrue it becomes apparent that the object of his vitriolic rejections is not any single member of the social orden but rather the social whole itself". 
sin más derecho que ser los compradores blancos y los comprados negros; los embarcan como brutos, los llevan millares de leguas desnudos, hambrientos y sedientos; los desembarcan en América; los venden en público mercado como jumentos, a más precio los mozos sanos y robustos, y a mucho más las infelices mujeres que se hallan con otro fruto de miseria dentro de sí mismas; toman el dinero; se lo llevan a sus humanísimos países, y con el producto de esta venta imprimen libros llenos de elegantes inventivas, retóricos insultos y elocuentes injurias contra Hernán Cortés por lo que hizo"108.

Como se ha señalado ${ }^{109}$, hay que poner esta crítica en relación con las circunstancias históricas del momento: una vez terminado el monopolio que ejercía la Compañía de Guinea establecida en Francia para la introducción de esclavos (asiento de negros) en las Indias, los británicos aprovechan el Tratado de Utrecht (1713) para apoderarse del mismo durante treinta años ${ }^{110}$. Cadalso no sólo recalca la inmoralidad del negocio, ya de por sí escandalosa y, dicho sea de paso, criticada por Montesquieu ${ }^{111}$, sino que lo incluye dentro de una pretensión europea de búsqueda de provecho que no se detiene ante nada. Aquí, me parece, que cabe ver una coincidencia con lo señalado por Montesquieu en Del espíritu de las leyes, donde se alude a dos formas diferentes de dominio:

"Los españoles consideraron al principio las tierras descubiertas como objeto de conquista: pueblos más sutiles que ellos las vieron como objeto de comercio, y en este sentido orientaron sus miras. Varios pueblos procedieron con tanto acierto, que pusieron el imperio en manos de compañías de traficantes, quienes, gobernando los Estados únicamente para el comercio, dieron origen a una gran potencia accesoria que no estorbaba al Estado principal" 112 .

¿Quiénes eran estos pueblos más sutiles que suministran "hombres para el trabajo de las minas y de las tierras de América"? Montesquieu responde poco después: "Europa hace el comercio y la navegación de las otras tres partes del mundo, del mismo modo que Francia, Inglaterra y Holanda hacen casi toda la navegación y el comercio de Europa"113.

\footnotetext{
${ }_{108}$ Cartas marruecas IX, p. 182.

109 H.-J. Lope, “ "Pongamos la fecha desde hoy....”. Historia e historiografía en las "Cartas marruecas"”, op. cit., p. 217.

110 "Tratado del asiento de negros concluido en Madrid el 26 de marzo de 1713 entre España e Inglaterra", en A. del Cantillo, ed., Tratados de paz y de comercio, desde el año 1700 hasta el día. Madrid. Imprenta de Alegría y Charlain, 1853, p. 58. Consultado 3.III.2013. Accesible en http:// books.google.es/books?id=ersCAAAAYAAJ\&printsec $=$ titlepage\&source=gbs_summary_r\&cad=0\# $\mathrm{v}=$ onepage $\& \mathrm{q} \& \mathrm{f}=$ false.

${ }^{111}$ Del espíritu de las leyes XV, en general y, especialmente, cap. V. No aceptan el carácter irónico de este capítulo J. Andrés-Gallego, "Los argumentos esclavistas y los argumentos abolicionistas: reconsideración necesaria”, Revista del CESLA, 7, 2005, pp. 63-108 (75) y Juan Francisco Martínez Peria, "Cautivos del clima. El problema de la esclavitud en el pensamiento de Montesquieu", Bajo Palabra. Revista de Filosofia, 5, 2010, pp. 215-228.

112 Ibid., XXI, XXI, p. 301.

113 Ibid., p. 302.
} 
Así pues, los españoles controlan la mayor parte de América, pero también franceses, ingleses, holandeses, rusos y cualesquier otros países europeos, si se lo podían permitir, materializaban su ansia de dominio sobre el resto del mundo. Cualquier método era válido. La plata que los españoles traían de Indias no sólo fluía hacia Europa para pagar sus necesidades y lujos; también les era arrebatada por piratas y corsarios ${ }^{114}$, ensalzados como grandes hombres en sus países $^{115}$. Una feroz competencia entre europeos abría la puerta al expolio de otros territorios mediante los más variados procedimientos, desde un Derecho natural y de gentes cuya "práctica ha hecho comunes los bienes de todos los hombres" $" 116$, hasta la pura conquista y el comercio más indigno. Dirigir la censura solo a lo hecho por los españoles y guardar silencio sobre lo propio le parecía a Cadalso no sólo desproporcionado sino, sobre todo, injusto.

\begin{abstract}
"Créeme, Gazel, créeme que si me diesen a escoger entre morir entre las ruinas de mi patria en medio de mis magistrados, parientes, amigos y conciudadanos, y ser llevado con mi padre, mujer e hijos millares de leguas metido en el entrepuentes de un navío, comiendo habas y bebiendo agua podrida, para ser vendido en América en mercado público, y ser después empleado en los trabajos más duros hasta morir, oyendo siempre los últimos ayes de tanto moribundo amigo, paisano o compañero de mis fatigas, no tardara en escoger la suerte de los primeros" $" 117$.
\end{abstract}

Es evidente que con esta argumentación Cadalso quiere defender a su país, con lo que la disputa se sitúa en el terreno político y apologético que tanta literatura estaba destinada a producir con el tiempo ${ }^{118}$. Pero el gaditano también viene a llamar la atención sobre dos de los dogmas más extendidos entre los ilustrados y que mayor autocomplacencia generan entre los mismos: el del progreso y el del cosmopolitismo. La presencia del primero en Montesquieu se manifiesta en su orgullo por el momento que le ha tocado vivir. Orgullo que en relación con el auge del comercio le lleva a decir que "No hay pues que extrañarse de que nuestras costumbres sean menos feroces que en otros tiempos" 119 , mientras en lo que se refiere al derecho de conquista le exalta todavía más: "hemos de rendir homenaje a los tiempos modernos, a la razón de nuestro tiempo, a nuestra religión, a nuestra filosofía y a nuestras costumbres" ${ }^{120}$. Este entusiasmo es el que lleva a Cadalso a la

114 Cartas marruecas XLIV, p. 253.

115 Ibid., LVII, p. 275.

${ }^{116}$ Los eruditos a la violeta, p. 37.

117 Cartas marruecas IX, pp. 187-88.

118 E. y E. García Camarero, eds., La polémica de la ciencia española, Madrid, Alianza, 1970; R. García Cárcel, La Leyenda Negra. Historia y opinión, Madrid, Alianza, 1998; Ma. J. Villaverde Rico y F. Castilla Urbano (Directores), La sombra de la leyenda negra, Madrid, Tecnos, 2016.

119 Del espíritu de las leyes, XX, I, 265.

${ }^{120}$ Del espíritu de las leyes, X, III, 140. 
crítica: "Los europeos del siglo presente están insufribles con las alabanzas que amontonan sobre la era en que han nacido"121. El elogio ilustrado por "la excelencia de nuestro siglo, sobre todos los demás pasados, y futuros", tal vez no esté justificado y deba variar en el futuro ${ }^{122}$. Si se cambia la perspectiva, se verá que no hay tantos motivos para creer que se han solucionado los males civiles ni morales de épocas pasadas:

"Quien escriba sin lisonja la historia, dejará a la posteridad horrorosas relaciones de príncipes dignísimos destronados, quebrantados tratados muy justos, vendidas muchas patrias dignísimas de amor, rotos los vínculos matrimoniales, atropellada la autoridad paterna, profanados juramentos solemnes, violado el derecho de hospitalidad, destruida la amistad y su nombre sagrado, entregados por traición ejércitos valerosos, y sobre las ruinas de tantas maldades levantarse un suntuoso templo al desorden general" ${ }^{123}$.

Respecto al dogma del cosmopolitismo, Cadalso no reniega de sus virtudes ${ }^{124}$, pero es consciente de las contradicciones que esconde, especialmente cuando se trata de escribir la historia en general y la de la conquista en particular. La crítica de las Luces se ceba con los excesos de los españoles en el pasado e ignora el triste presente en el que están empeñados sus propios países:

"A lo que debes añadir que, habiendo cesado tantos años ha la mortandad de los indios, tal cual haya sido, y durando todavía con trazas de nunca cesar la venta de los negros, serán muy despreciables a los ojos de cualquier hombre imparcial, cuanto nos digan y repitan sobre este capítulo, en verso o en prosa, en estilo serio o jocoso, en obras voluminosas o en hojas sueltas, los continuos mercaderes de carne humana" ${ }^{125}$.

El argumento cadalsiano permitía, por lo demás, aludir a otro aspecto del pensamiento de Montesquieu que el gaditano podía tener presente al criticar este comercio de vidas humanas. El señor de la Brède no solo elogiaba el comercio como alternativa a la conquista sino que hace de este el signo distintivo de una época orgullosa de sus logros: "No hay pues que extrañarse de que nuestras costumbres sean menos feroces que en otros tiempos" ${ }^{\text {"126. Dado }}$ que "el efecto natural del comercio es la paz"127, no se puede negar su poder civilizador, lo que hace del mismo un generador de virtudes como la frugalidad,

${ }^{121}$ CM IV, p. 161.

${ }^{122}$ Los eruditos a la violeta, ed. cit., p. 57.

${ }^{123}$ CM IV, p. 162.

${ }^{124}$ Ibídem, LXXX, p. 335: Nuño es "un verdadero cosmopolita, o sea ciudadano universal", que considera "todos mis hermanos los hombres" (ibídem, VIII, p. 180) y que "Todos mis conocidos son mis amigos" (Ibídem, XL, p. 244).

${ }^{125}$ Cartas marruecas IX, p. 188.

${ }^{126}$ Del espiritu de las leyes, XX, I, 265.

${ }^{127}$ Ibídem, XX, II, 266. 
la economía, la moderación, el trabajo, la prudencia, la tranquilidad, el orden y la regla ${ }^{128}$. Es más, aunque la práctica del comercio corrompe los hábitos que pueden beneficiar la aptitud para la guerra, hay que vincularlo más con la virtud, porque "cura los prejuicios destructores", "suaviza las costumbres bárbaras" y facilita su conocimiento y comparación, de lo que "han resultado grandes beneficios" ${ }^{29}$. Se comprende que de su práctica sobrevenga el incremento de la población ${ }^{130}$ y la mejora de la comunicación entre los pueblos ${ }^{131}$.

Al convertir el comercio en un rasgo de las naciones modernas opuesto al espíritu de conquista aplicado por España, Montesquieu colocaba a esta en el rincón de los vicios que todas las demás debían evitar. Lo que Cadalso venía a denunciar era que una parte importante de ese comercio era tan indigna como la propia conquista y que la violencia y mortandad que provocaba no era menor. De esta forma, echaba por tierra la superioridad moral atribuida al comercio, a la vez que cuestionaba las consecuencias generales de carácter económico que Montesquieu extraía de su práctica. En efecto, el señor de la Brède había convertido el comercio en una práctica buena para la propia sociedad y para la humanidad, pues "el efecto del comercio es la riqueza; la consecuencia de las riquezas es el lujo, y la del lujo, la perfección de las artes"132. Sin embargo, también esta generalización debía ser matizada por Cadalso, pues no solo cabe rechazar el comercio de personas sino que el lujo no puede ser adecuado para un país que debe adquirir los artículos de lujo en el exterior a costa de empobrecerse. Lo que procedía era un lujo que fomentase la industria nacional, verdadera fuente de riqueza:

\begin{abstract}
"Volviendo al lujo extranjero y nacional, este, en la antigüedad que he dicho, consistía, a más de varios artículos ya olvidados, en lo exquisito de sus armas, abundancia y excelencia de sus caballos, magnificencia de sus casas, banquetes de increíble número de platos para cada comida, fábricas de Segovia y Córdoba, servicio personal voluntario al soberano, bibliotecas particulares, etc.; todo lo cual era producto de España y se fabricaba por manos españolas. Vuélvanse a fomentar estas especies y, consiguiéndose el fin político del lujo (que, como está ya dicho, es el reflujo de los caudales excesivos de los ricos a los pobres) se verán en breves años multiplicarse la población, salir de la miseria los necesitados, cultivarse los campos, adornarse las ciudades, ejercitarse la juventud y tomar el Estado su antiguo vigor. Este es el cuadro del antiguo lujo. ¿Cómo retrataremos el moderno? Copiemos los objetos que se nos ofrecen a la vista, sin lisonjearlos ni ofenderlos"133.
\end{abstract}

${ }^{128}$ Ibídem, V, VI, 81; véase la aplicación de una enumeración similar a propósito de Marsella (XX, $\mathrm{V}, 268)$.

${ }^{129}$ Ibídem, XX, I, 265-66; E. Martínez Mata, "Cadalso y Montesquieu: lujo y doux commerce", eHumanista 27 (2014), pp. 63-70.

${ }^{130}$ Cartas persas, CXV, 165.

${ }^{131}$ Del espiritu de las leyes, XXI, V, 277.

${ }_{132}$ Ibídem, XXI, VI, 277.

${ }_{133}$ Cartas marruecas XLI, p. 248.

Araucaria. Revista Iberoamericana de Filosofia, Política, Humanidades y Relaciones Internacionales, año 20, $\mathrm{n}^{\circ} 40$ Segundo semestre de 2018. Pp. 75-107. ISSN 1575-6823 e-ISSN 2340-2199 doi: 10.12795/araucaria.2018.i40.04 
Es decir, un lujo que fomentara la industria nacional haría revivir las virtudes patrias, mientras que el lujo por el lujo, tal y como el pensador francés lo postulaba, solo serviría para seguir manteniendo la pobreza nacional. De esta forma, además del progreso y el cosmopolitismo, también la economía se convertía en objeto de matización. Montesquieu podía ilustrar al mundo de las luces con su filosofía, pero era necesario medir bien el alcance de sus ideas para ver si efectivamente eran válidas de manera generalizada o, por el contrario, debían ser reformadas y adaptadas a cada circunstancia. Incluso la propia consideración de sus interpretaciones históricas debía someterse a este principio.

\section{De la imparcialidad historiográfica}

La ausencia de imparcialidad al juzgar los hechos, de valoraciones similares para el presente propio y el pasado hispano, traslada el debate al terreno de las ideas y de la metodología historiográfica; este asunto no es del todo ajeno al anterior, pero tiene su dimensión propia. El planteamiento de partida es que la parcialidad que muestran los historiadores ilustrados amenaza con anular cualquier relato que pretenda dar cuenta de la historia universal. Los historiadores ingleses $\mathrm{y}$ franceses que quieren encarnar en sus ideales y discursos esos valores apenas son capaces de superar el localismo de los historiadores particulares; escriben historias que pretenden ser globales e ignoran por igual a los grandes hombres y los acontecimientos más importantes del resto de los países. Como dice Cadalso: "Creo que se quejarán de igual descuido las demás naciones, menos la del autor"134. Cuando se habla de los españoles, las lagunas son todavía mayores: Nuño se muestra siempre quejoso "de que los franceses no sean igualmente imparciales cuando hablan de los españoles"135 y Cadalso, para disculpar a Montesquieu, denuncia muy tempranamente esa misma falta de imparcialidad, además de ligereza y superficialidad, en lo escrito por quienes acompañaban a Felipe $V$ en su venida a España ${ }^{136}$. La consecuencia más directa de esta insuficiencia de la historiografía cosmopolita es la desconfianza en sus producciones:

"Dicen en Europa que la historia es el libro de los reyes. Si esto es así, y la historia se prosigue escribiendo como hasta ahora, creo firmemente que los reyes están destinados a leer muchas mentiras, a más de las que oyen. No dudo que una relación exacta de los hechos principales de los hombres, y una noticia de la formación, auge, decadencia y ruina de los estados, darían en breves hojas a un príncipe lecciones de lo que ha de hacer, sacadas de lo que otros han hecho. Pero ¿dónde se halla esta relación y esta noticia? No la hay" ${ }^{137}$.

${ }^{134}$ Ibid., LVII, p. 276.

${ }^{135}$ Ibid., XXIX, p. 226.

${ }^{136}$ Defensa de la nación española, p. 11.

137 Cartas marruecas LIX, p. 279. Sobre la primera frase del párrafo, que Emilio Martínez Mata en 
No la hay ni la puede haber porque los relatos históricos están plagados de intereses nacionales; intereses que impiden que se escriba con imparcialidad lo que ocurre en ese momento y que transmiten a las siguientes épocas versiones prejuiciadas de lo acontecido ${ }^{138}$. Al denunciar esta deriva de las historias al uso, Cadalso no piensa, al menos en primera instancia, en el "subjetivismo de los que escriben la historia"139, sino en la "razón de estado"; es decir, está advirtiendo, en el siglo cosmopolita por excelencia, sobre el nacionalismo que impide escribir un relato acorde con aquella ideología. De hecho, ante la pretensión de solucionar las dificultades de escribir una historia contemporánea recurriendo "a algún hombre lleno de crítica, imparcialidad y juicio", detalla con mayor detalle los obstáculos que la impiden: "¿Y dónde se imprimiría?... ¿Y quién la leería? ¿Y qué efectos produciría? ¿Y qué pago tendría el escritor?"140. Allí donde Montesquieu señala las dificultades para que los historiadores alcancen la verdad bien porque lo impide el régimen despótico en el que viven o porque, gozando de libertad, son incapaces de superar su partidismo ${ }^{141}$, Cadalso parece dejar de lado la subjetividad del relator y prefiere señalar elementos vinculados a las circunstancias (objetivas) de origen del texto, posibles lectores, aceptación de lo escrito y recompensa del autor. Incluso se recurre a unos imaginarios lectores libres de prejuicios por su lejanía, su rousseauniana bondad natural ${ }^{142}$ y su ausencia de interés propio en el relato, para que certifiquen mediante hipérbole la imposibilidad de abordar una narración libre de nacionalismo:

\begin{abstract}
"era menester imprimirla junto al cabo de Hornos o al de Buena Esperanza, y leerla a los hotentotes o a los patagones, y aun así me temo que algunos sabios de los que habrá sin duda a su modo entre aquéllos que nosotros nos servimos llamar salvajes, dirían al oír tantos y tales sucesos al que los estuviera leyendo: 'Calla, calla, no leas esas fábulas llenas de ridiculeces y barbaridades'; y los mozos proseguirían su danza, caza o pesca, sin creer que hubiese en el mundo conocido parte alguna donde pudiesen suceder tales $\operatorname{cosas}^{143}$.
\end{abstract}

\footnotetext{
su citada edición de las Cartas marruecas (p. 297) asocia “a la concepción de la historia sintetizada en la conocida frase de Bossuet: la historia como "sage conseillère des princes" ("prudente consejera de los príncipes')", creo que remite a la Historia de la conquista de México de Antonio de Solís, en Historiadores de sucesos particulares II. B.A.E. XXVIII. Madrid. Ediciones Atlas, 1948, pp. 205-387 (p. 205): "Llamó la venerable antigüedad libros de reyes a las historias, o porque se componen de sus acciones y sucesos, $o$ porque su principal enseñanza mira derechamente a las artes del reinar, pues se colige de la variedad de sus ejemplos lo que puede recelar la prudencia y lo que debe abrazar la imitación".

${ }^{138}$ Ibid.: "Un hecho no se puede escribir sino en el tiempo en que sucede, o después de sucedido. En el tiempo del evento, ¿qué pluma se encargará de ello, sin que la detenga la razón de estado, o alguna preocupación? Después del caso, ¿sobre qué ha de trabajar el historiador que lo transmita a la posteridad, sino sobre lo que dejaron escrito las plumas que he referido?".

139 H.-J. Lope, “"Pongamos la fecha desde hoy...". Historia e historiografía en las "Cartas marruecas"”, op. cit., p. 219.

140 Cartas marruecas LIX, p. 280.

${ }^{141}$ Del espíritu de las leyes XIX, XXVII, p. 264.

142 J. Yagüe Bosch, “Aspectos de la visión de América en los ilustrados”, op. cit., p. 646.

143 Cartas marruecas LIX, p. 280.
} 
Desde esta perspectiva cobra sentido la crítica cadalsiana a cuantos comentarios considere faltos de veracidad sobre su país, especialmente si pertenecen a un autor tan prestigioso, admirado y familiar como lo es Montesquieu para el gaditano. En concreto, deberíamos plantearnos si los textos reivindicativos de la historia de España que se insertan sucesivamente en la Defensa de la nación española ${ }^{144}$ y en las Cartas marruecas ${ }^{145}$, a pesar de alguna concesión ${ }^{146}$, no son respuesta al resumen que aparece en la CXXXVI de las Cartas persas:

"[los historiadores] representan la nación española saliendo de las breñas de los montes; los príncipes mahometanos tan lentamente vencidos como fueron rápidas sus victorias; tantos reinos reunidos en una vasta monarquía que casi llegó a ser la única, hasta que con su propia grandeza y su falaz opulencia abrumada perdió su fuerza y su reputación, sin conservar más que la vana arrogancia de su antiguo poderío"147.

A estas réplicas hay que añadir la crítica de la información transmitida por los viajeros, llena de errores e inexactitudes, que se lleva a cabo en la exaltada Defensa de la nación española y, sobre todo, más tardíamente pero con mayor ironía y elaboración, en el Suplemento al papel intitulado Los eruditos a la violeta. Estos dos textos vienen a censurar a Montesquieu por haber hecho suyos los datos que pudieron llegarle sobre España y por haberlos transmitido sin ninguna comprobación en las Cartas persas ${ }^{148}$.

En la misma línea reivindicativa, también las Cartas marruecas incluyen respuestas alternativas, más sutiles y moderadas que las citadas, a la LXXVIII de las Cartas persas. Es el sentido que tiene la explicación de Gazel a BenBeley, que se justifica por no darle noticias de España hasta que no se familiarice con el país:

"Sólo con notar cuatro o cinco costumbres extrañas, cuyo origen no me tomaría el trabajo de indagar, ponerlas en estilo suelto y jocoso, añadir algunas reflexiones satíricas, y soltar la pluma con la misma ligereza que la tomé, completaría mi obra, como otros muchos lo han hecho"149.

144 Defensa de la nación española, p. 6-11.

145 Cartas marruecas III, p. 157-160.

146 Compárese Del espíritu de las leyes XXI, XXII, p. 302-303, ya citado, con este párrafo de Cartas marruecas III, p. 159: Felipe II "fue tan ambicioso y político como su padre, pero menos afortunado, de modo que, siguiendo los proyectos de Carlos, no pudo hallar los mismos sucesos aun a costa de ejércitos, armadas y caudales gastados en propagar las ideas de su ambición. Murió dejando su pueblo extenuado con las guerras, afeminado con el oro y plata de América, disminuido con la población de un mundo nuevo, disgustado con tantas desgracias y deseoso de descanso".

147 Cartas persas CXXXVI, p. 197, cursiva nuestra; véase ibid., II, p. 156.

148 Suplemento al papel intitulado Los eruditos a la violeta, op. cit., p. 72-73; Defensa de la nación española, p. 10-14.

149 Cartas marruecas I, p. 154.

Araucaria. Revista Iberoamericana de Filosofia, Política, Humanidades y Relaciones Internacionales, año $20, \mathrm{n}^{\circ} 40$. Segundo semestre de 2018. Pp. 75-107. ISSN 1575-6823 e-ISSN 2340-2199 doi: 10.12795/araucaria.2018.i40.04 
Pero, merece la pena destacar una que parece claramente encaminada a recoger el reto lanzado por Montesquieu al final de esa carta: "Mucho celebraría, Usbek, -decía allí- ver una carta escrita a Madrid por un español que viajase por Francia, que bien creo que vengaría su nación"150. Pues bien, ese sentido tiene la carta marrueca XXIX, dirigida por Gazel a Ben-Beley describiendo los usos franceses pero, sobre todo, reproduciendo unas palabras de Nuño Núñez en las que combina la alabanza de Francia y especialmente de su juventud con la queja de que los franceses no son "imparciales cuando hablan de los españoles"151. Me interesa destacarla y finalizar con su mención porque refleja muy bien lo que parece haber sido en todo momento el sentimiento de Cadalso: admiración por Francia, por su cultura, por sus escritores, con una consideración muy especial hacia Montesquieu, pero, a la vez, defensa de España, de su historia y recelo ante unas críticas que, en varios asuntos pero más en relación con América, consideró excesivas.

${ }^{150}$ Cartas persas LXXVIII, p. 117.

151 Cartas marruecas XXIX, p. 226. 


\section{Referencias bibliográficas:}

Andrés-Gallego, José, "Los argumentos esclavistas y los argumentos abolicionistas: reconsideración necesaria", Revista del CESLA, 7, 2005, pp. 63-108.

Andreu Miralles, X., “¿"Razón crítica” vs. "sentimiento patriótico”?: Cadalso y el carácter nacional”, en $\mathrm{M}^{\mathrm{a}}$ E. Nicolás Marín y C. González Martínez, coords., Ayeres en discusión: temas clave de Historia Contemporánea hoy, recurso electrónico, 2009; consultado 20.XII.2012, accesible en http://www.ahistcon.org/docs/murcia/contenido/pdf/08/xavier_andreu_ miralles_taller08.pdf.

Artola, M., "América en el pensamiento español del siglo XVIII", Revista de Indias, 29, 1969, pp. 51-77.

Barrera, G., "Espagne", Dictionnaire électronique Montesquieu [En ligne], mis à jour le: 13/02/2008, URL: http://w7.ens-lsh.fr/dictionnaire-montesquieu/ index.php?id=321 (Consulta 1.VI.2013).

Barrera, G., 'La figure de l'Espagne dans l'œuvre de Montesquieu: élaboration conceptuelle d'un exemple, stratégie d'écriture et mode d'avertissement", Actes du Colloque international de Bordeaux 1998, Académie de Bordeaux, 1999, pp. 153-71.

Barriére, P., "Montesquieu et 1'Espagne", Bulletin Hispanique, 49, 3-4, 1947, pp. 299-310.

Bermúdez-Cañete, F., "Cadalso en su contexto europeo", Cuadernos Hispanoamericanos, CXXX, 389, 1982, pp. 263-78.

Cadalso, J. de, Cartas marruecas. Noches lúgubres, edición de E. Martínez Mata Barcelona, Crítica, 2000.

Cadalso, J. de, Cartas marruecas. Prólogo, edición y notas de L. Dupuis y N. Glendinining, London, Tamesis Books Limited, 1966.

Cadalso, J. de, Defensa de la nación española contra la carta persiana LXXVIII de Montesquieu, ed. G. Mercadier, Université de Toulouse, France-Iberie Recherche, 1970.

Cadalso, J. de, Escritos autobiográficos y epistolario, ed. N. Glendinning y N. Harrison, London, Tamesis Books Limited, 1979.

Cadalso, J., Cartas marruecas. Noches lúgubres, ed. R. P. Sebold, Madrid, Cátedra, $2006^{6}$.

Cantillo, A. del, ed., Tratados de paz y de comercio, desde el año 1700 hasta el día. Madrid. Imprenta de Alegría y Charlain, 1853, p. 58. Consultado 3.III.2013. Accesible en http://books.google.es/books?id=ersCAAAAYA AJ\&printsec $=$ titlepage \&source $=\mathrm{gbs} \_$summary_r\&cad $=0 \# \mathrm{v}=$ onepage \&q $\& \mathrm{f}=$ false. 
Castilla Urbano, F., "Conquista y comercio: la visión colonial de Montesquieu”, en F. Castilla Urbano (Editor), Visiones de la conquista y la colonización de las Américas. Universidad de Alcalá, 2015, pp. 89-106.

Castilla Urbano, F., "Guerra y patriotismo en el ilustrado José Cadalso", en J. R. Cirici Narváez y A. Ramos Santana (coords.), La furia de Marte. Ideología, pensamiento y representación. XIV Encuentro de la Ilustración al Romanticismo. España, Europa y América (1750-1850). Universidad de Cádiz, 2012, pp. 211-27.

Castilla Urbano, F., "La conquista y colonización de América en Cadalso: entre el patriotismo y la Ilustración”, Revista de Estudios Políticos, 167 (2015), pp. 33-57.

Castilla Urbano, F., "La Historia de la conquista de México de Antonio de Solís en la obra de José Cadalso y sus fuentes francesas", en G. Franco Rubio, N. González Heras y E. de Lorenzo Álvarez (coords.), España y el continente americano en el siglo XVIII. Gijón. SEES XVIII - Ediciones Trea, 2017, pp. 827-841.

Cotton, E., "Cadalso and his foreign sources", Bulletin of Spanish Studies, VIII, 29, 1931, pp. 5-18.

Demerson, J., “Cadalso, la Religión y la Iglesia”, en J. Amor y Vázquez y A. D. Kossoff, eds., Homenaje a Juan López-Morillas. De Cadalso a Aleixandre: Estudios sobre literatura e historia intelectual españolas, Madrid, Castalia, 1982, pp. 151-69.

Díez del Corral, L., El pensamiento político europeo y la monarquía de España, Madrid, Alianza Ed., 1983 (1975).

Domínguez, A., "Las Lettres persanes y las Cartas marruecas: la función de la perspectiva en la crítica social de dos novelas epistolares", en F. Lafarga (Ed.), Imágenes de Francia en las letras hispánicas, Barcelona, PPU, 1989, pp. 47-55.

Étienvre, F., "Montesquieu y Voltaire: sus visiones de España", en J. Checa Beltrán (Ed.), Lecturas del legado español en la Europa ilustrada. Madrid. Iberoamericana Vervuert, 2012, pp. 67-103.

Ezquerra, R., "La crítica española de la situación de América en el siglo XVIII", Revista de Indias, 22, 1962, pp. 159-287.

Fabbri, M., "Don José Cadalso relator de las "Cartas marruecas"”, Coloquio Internacional sobre José Cadalso. Bolonia, 26-29 de Octubre de 1982, Albano Terme, Piovan Editore, 1985.

Felice, D., "Francia, Spagna e Portogallo: le monarchie europee "qui vont au despotisme" secondo Montesquieu”, Cahiers Montesquieu, 2, 1995, p. 283-305. 
Fernández Albadalejo, P., "Entre la "gravedad" y la "religión": Montesquieu y la "tutela" de la Monarquía católica en el primer setecientos", en A. Mestre, P. Fernández Albaladejo y E. Giménez López, coords., Monarquía, imperio y pueblos en la España moderna (V. I). Actas de la IV Reunión Científica de la Asociación Española de Historia Moderna Alicante, 27-30 de mayo de 1996, 1997, pp. 3-24.

Foulché-Delbosc, R., ed., "Obras inéditas de Don José Cadalso", Revue Hispanique, I, 1894, pp. 258-335.

Froldi, R., "La conquista dell'America e Cadalso", edición digital a partir de la separata de Studi di Iberistica in memoria di Alberto Boscoso, Roma, Bulzoni, 1989,pp.113-27, consultado 10.XII.2008, accesibleenhttp://www. cervantesvirtual.com/servlet/SirveObras/23586286543403851965679/ index.htm.

García Camarero, E. y E., eds., La polémica de la ciencia española, Madrid, Alianza, 1970.

García Cárcel, R., La Leyenda Negra. Historia y opinión, Madrid, Alianza, 1998.

García Marqués, A. y Ma del M., "Dimensiones historiográficas de las Cartas Persas de Montesquieu y las Cartas Marruecas de Cadalso", Revista de la Facultad de Humanidades de Jaén, 2, 2, 1993, pp. 21-47.

Glendinning, N., "Ideas políticas y religiosas de Cadalso", Cuadernos Hispanoamericanos, 389, 2, 1982, pp. 247-62.

Goulemot, J.-M., 'L'Espagne de Montesquieu", Bulletin de la Société Montesquieu, 7, 1995, pp. 16-26.

Hughes, John B., José Cadalso y las Cartas Marruecas, Madrid, Tecnos, 1969. Hume, D., Tratado de la naturaleza humana. Ed. de F. Duque. Madrid. Tecnos, 2005.

Iarocci, M., Properties of Modernity. Romantic Spain, Modern Europe, and the Legacies of Empire. Nashville. Vanderbilt University Press, 2006.

Iglesias, C., "Montesquieu et l'Espagne", Transactions of the Seventh International Congress on the Enlightenment, Studies on Voltaire and the Eighteenth Century, CCLXIII-CCLXV, 1989, pp. 173-75.

Iglesias, M. C., "Montesquieu and Spain: Iberian Identity as Seen through the Eyes of a Non-Spaniard of the Eighteenth Century", en R. Herr y J. Polt, ed., Iberian Identity: Essays on the Nature of Identity in Portugal and Spain. Berkeley. University of California. Institute of International Studies, 1989, pp. 143-55.

Laborde, P., "Cadalso et Montesquieu”, Revue des Langues Romanes, LXXI, 1952, pp. 171-80. 
Lope, H.-J., "“"Pongamos la fecha desde hoy...”. Historia e historiografía en las "Cartas marruecas"”, Coloquio Internacional sobre José Cadalso. Bolonia, 26-29 de Octubre de 1982, Albano Terme, Piovan Editore, 1985, pp. 211-33.

Lope, H.-J., “Cadalso y Hernán Cortés”, Dieciocho, 9, 1986, pp. 188-200.

Lopez, F., "Cadalso y la cuestión nacional", Coloquio Internacional sobre José Cadalso. Bolonia, 26-29 de Octubre de 1982, Albano Terme, Piovan Editore, 1985, pp. 235-55.

Lopez, F., "De las Lettres persanes a las Cartas marruecas", en J.-P. Sánchez, coord., Ville et campagne en Espagne au XVIIIe. Siècle, Paris, Éditions du Temps, 1997, pp. 174-90.

Lopez, F., "La stratégie des Cartas marruecas", en C. Serrano, J.-P. Duviols y A. Molinié, eds., Les voies des Lumières. Le monde ibérique au XVIIIe siècle, Presses de l'Université de Paris-Sorbonne, 1998, pp. 67-78.

Martínez Mata, E., "Cadalso y Montesquieu: lujo y doux commerce", eHumanista 27 (2014), pp. 63-70.

Martínez Peria, Juan Francisco, "Cautivos del clima. El problema de la esclavitud en el pensamiento de Montesquieu", Bajo Palabra. Revista de Filosofía, 5, 2010, pp. 215-228.

Montesquieu, Cartas persas, trad. de J. Marchena, estudio preliminar de J. M. Colomer, Madrid, Tecnos, 1986 (1721).

Montesquieu, Consideraciones sobre las causas de la grandeza y decadencia de los romanos. Tarragona. Imprenta de M. Puigrubi, 1835 (1734).

Montesquieu, Del espíritu de las leyes, trad. de M. Blázquez y P. de Vega, prólogo de E. Tierno Galván, Madrid, Tecnos, 1980.

Raimondi Capasso, M., "Cadalso et Rousseau", Acme: Annali della Facoltà di lettere e filosofia dell'Università degli studi di Milano, 20, 1967, pp. 97-116.

Reding, K., "A study of the influence of Oliver Goldsmith's Citizen of the World upon the Cartas marruecas of José Cadalso", Hispanic Review, 2, 3, 1934, pp. 226-34.

Solís, Antonio de, Historia de la conquista de México, en Historiadores de sucesos particulares II. B.A.E. XXVIII. Madrid. Ediciones Atlas, 1948, pp. 205-387.

Tamayo y Rubio, J., "Cartas Marruecas del Coronel D. Joseph Cadahalso", Anales de la Facultad de Filosofía y Letras (Universidad de Granada), 2, 1926, pp. 123-36 y 3, 1927, pp. 7-85.

Vázquez, J. (seudónimo de J. Cadalso), Los eruditos a la violeta, reproducción de la edición de Madrid, Sancha, 1772, con introducción de M. Á. Vázquez Medel, Madrid, Ediciones Alfar, 1982. 
Vázquez, J. (seudónimo de J. Cadalso), Suplemento al papel intitulado Los eruditos a la violeta, reproducción de la edición de Madrid, Sancha, 1772, Sevilla, Ediciones Alfar, 1983.

Villaverde Rico, Ma. J., y F. Castilla Urbano (Directores), La sombra de la leyenda negra, Madrid, Tecnos, 2016.

Yagüe Bosch, J., "Aspectos de la visión de América en los ilustrados", Cauce, 14-15, 1992, pp. 639-68.

Yagüe Bosch, J., «Defensa de España y conquista de América en el siglo XVIII: Cadalso y Forner», Dieciocho, 28, I, 2005, pp. 121-40. 
